\title{
Evaluation of the absorption Ångström exponents for traffic and wood burning in the Aethalometer-based source apportionment using radiocarbon measurements of ambient aerosol
}

\author{
Peter Zotter $^{1, a}$, Hanna Herich ${ }^{2, b}$, Martin Gysel ${ }^{1}$, Imad El-Haddad ${ }^{1}$, Yanlin Zhang ${ }^{1,3,4,5, c}$, Griša Močnik ${ }^{6,7}$, \\ Christoph Hüglin $^{2}$, Urs Baltensperger ${ }^{1}$, Sönke Szidat ${ }^{3,4}$, and André S. H. Prévôt ${ }^{1}$ \\ ${ }^{1}$ Laboratory of Atmospheric Chemistry, Paul Scherrer Institute (PSI), 5232 Villigen PSI, Switzerland \\ ${ }^{2}$ Laboratory for Air Pollution and Environmental Technology, Swiss Federal Laboratories for Materials Science \\ and Technology (Empa), Überlandstrasse 129, 8600 Dübendorf, Switzerland \\ ${ }^{3}$ Department of Chemistry and Biochemistry, University of Bern, Bern, Switzerland \\ ${ }^{4}$ Oeschger Centre for Climate Change Research, University of Bern, Bern, Switzerland \\ ${ }^{5}$ Laboratory of Radiochemistry and Environmental Chemistry, Paul Scherrer Institute (PSI), 5232 Villigen PSI, Switzerland \\ ${ }^{6}$ Research and Development Department, Aerosol d.o.o., Ljubljana, Slovenia \\ ${ }^{7}$ Condensed Matter Physics Department, Jožef Stefan Institute, Ljubljana, Slovenia \\ ${ }^{a}$ now at: Lucerne University of Applied Sciences and Arts, School of Engineering and Architecture, \\ Bioenergy Research, Technikumstrasse 21, 6048 Horw, Switzerland \\ ${ }^{b}$ now at: Kanton St.Gallen, Amt für Umwelt und Energie, 9001 St. Gallen, Switzerland \\ ${ }^{c}$ now at: Yale-NUIST Center on Atmospheric Environment, Nanjing University of Information Science \\ and Technology, 210044, Nanjing, China
}

Correspondence to: André S. H. Prévôt (andre.prevot@psi.ch)

Received: 13 July 2016 - Discussion started: 15 August 2016

Revised: 27 February 2017 - Accepted: 27 February 2017 - Published: 29 March 2017

\begin{abstract}
Equivalent black carbon (EBC) measured by a multi-wavelength Aethalometer can be apportioned to traffic and wood burning. The method is based on the differences in the dependence of aerosol absorption on the wavelength of light used to investigate the sample, parameterized by the source-specific absorption Ångström exponent $(\alpha)$. While the spectral dependence (defined as $\alpha$ values) of the traffic-related EBC light absorption is low, wood smoke particles feature enhanced light absorption in the blue and near ultraviolet. Source apportionment results using this methodology are hence strongly dependent on the $\alpha$ values assumed for both types of emissions: traffic $\alpha_{\mathrm{TR}}$, and wood burning $\alpha_{\mathrm{WB}}$. Most studies use a single $\alpha_{\mathrm{TR}}$ and $\alpha_{\mathrm{WB}}$ pair in the Aethalometer model, derived from previous work. However, an accurate determination of the source specific $\alpha$ values is currently lacking and in some recent publications the applicability of the Aethalometer model was questioned.
\end{abstract}

Here we present an indirect methodology for the determination of $\alpha_{\mathrm{WB}}$ and $\alpha_{\mathrm{TR}}$ by comparing the source apportionment of EBC using the Aethalometer model with ${ }^{14} \mathrm{C}$ measurements of the EC fraction on 16 to $40 \mathrm{~h}$ filter samples from several locations and campaigns across Switzerland during 2005-2012, mainly in winter. The data obtained at eight stations with different source characteristics also enabled the evaluation of the performance and the uncertainties of the Aethalometer model in different environments. The best combination of $\alpha_{\mathrm{TR}}$ and $\alpha_{\mathrm{WB}}$ (0.9 and 1.68, respectively) was obtained by fitting the Aethalometer model outputs (calculated with the absorption coefficients at 470 and $950 \mathrm{~nm})$ against the fossil fraction of $\mathrm{EC}\left(\mathrm{EC}_{\mathrm{F}} / \mathrm{EC}\right) \mathrm{de}-$ rived from ${ }^{14} \mathrm{C}$ measurements. Aethalometer and ${ }^{14} \mathrm{C}$ source apportionment results are well correlated $(r=0.81)$ and the fitting residuals exhibit only a minor positive bias of $1.6 \%$ and an average precision of $9.3 \%$. This indicates that the Aethalometer model reproduces reasonably well the ${ }^{14} \mathrm{C}$ re- 
sults for all stations investigated in this study using our best estimate of a single $\alpha_{\mathrm{WB}}$ and $\alpha_{\mathrm{TR}}$ pair. Combining the EC, ${ }^{14} \mathrm{C}$, and Aethalometer measurements further allowed assessing the dependence of the mass absorption cross section (MAC) of EBC on its source. Results indicate no significant difference in $\mathrm{MAC}$ at $880 \mathrm{~nm}$ between $\mathrm{EBC}$ originating from traffic or wood-burning emissions. Using $\mathrm{EC}_{\mathrm{F}} / \mathrm{EC}$ as reference and constant a priori selected $\alpha_{\mathrm{TR}}$ values, $\alpha_{\mathrm{WB}}$ was also calculated for each individual data point. No clear stationto-station or season-to-season differences in $\alpha_{\mathrm{WB}}$ were observed, but $\alpha_{\mathrm{TR}}$ and $\alpha_{\mathrm{WB}}$ values are interdependent. For example, an increase in $\alpha_{\mathrm{TR}}$ by 0.1 results in a decrease in $\alpha_{\mathrm{WB}}$ by 0.1 . The fitting residuals of different $\alpha_{\mathrm{TR}}$ and $\alpha_{\mathrm{WB}}$ combinations depend on $\mathrm{EC}_{\mathrm{F}}$ / $\mathrm{EC}$ such that a good agreement cannot be obtained over the entire $\mathrm{EC}_{\mathrm{F}} / \mathrm{EC}$ range using other $\alpha$ pairs. Additional combinations of $\alpha_{\mathrm{TR}}=0.8$, and 1.0 and $\alpha_{\mathrm{WB}}=1.8$ and 1.6 , respectively, are possible but only for $\mathrm{EC}_{\mathrm{F}} / \mathrm{EC}$ between $\sim 40$ and $85 \%$. Applying $\alpha$ values previously used in the literature such as $\alpha_{\mathrm{WB}}$ of $\sim 2$ or any $\alpha_{\mathrm{WB}}$ in combination with $\alpha_{\mathrm{TR}}=1.1$ to our data set results in large residuals. Therefore we recommend to use the best $\alpha$ combination as obtained here $\left(\alpha_{\mathrm{TR}}=0.9\right.$ and $\left.\alpha_{\mathrm{WB}}=1.68\right)$ in future studies when no or only limited additional information like ${ }^{14} \mathrm{C}$ measurements are available. However, these results were obtained for locations impacted by black carbon (BC) mainly from traffic consisting of a modern car fleet and residential wood combustion with well-constrained combustion efficiencies. For regions of the world with different combustion conditions, additional BC sources, or fuels used, further investigations are needed.

\section{Introduction}

Recently, the World Health Organization (WHO) reported around 3.7 million premature deaths in 2012 as a result of exposure to ambient air pollution, demonstrating that health risks in areas of low air quality are far greater than previously thought (WHO, 2014). Atmospheric particulate matter (PM) contributes significantly to ambient air pollution and adversely affects human health causing respiratory and cardiopulmonary diseases associated with increased morbidity and mortality (Pope and Dockery, 2006; WHO, 2006). Although PM levels were decreasing in the last decade in Europe and also in Switzerland, legal thresholds are still exceeded (Barmpadimos et al., 2011, 2012). Carbonaceous material (total carbon, TC) is a major fraction of the fine aerosol mass (up to $90 \%$ of the PM mass $<2.5 \mu \mathrm{m}$, Gelencsér, 2004; Putaud et al., 2004; Jimenez et al., 2009) and is further classified into the sub-fractions organic carbon (OC) and black carbon (BC) or elemental carbon (EC; Jacobson et al., 2000). $\mathrm{BC}$ is the light-absorbing part of carbonaceous material and, compared to other aerosol components, it contributes significantly to global warming due to its optical and radiative properties (Jacobson, 2001, 2010; IPCC, 2013). Because of the relatively short atmospheric lifetime of $\mathrm{BC}$, its radiative forcing ends within weeks after emission. Thus, reducing BC emissions may rapidly reduce climate warming (Shindell et al., 2012; Bond et al., 2013 and references therein). Therefore, the identification of different $\mathrm{BC}$ sources and their emission strength is crucial for the implementation of effective mitigation strategies.

The emission sources of $\mathrm{BC}$ are combustion processes of fossil and non-fossil carbonaceous fuels. In Switzerland, large parts of Europe and other parts of the world, BC mainly originates either from traffic or biomass burning in winter (e.g., Szidat et al., 2007; Favez et al., 2010; Lanz et al., 2010; Piazzalunga et al., 2011; Harrison et al., 2012; Larsen et al., 2012; Crippa et al., 2013; Herich et al., 2014). Different methods exist to quantify carbonaceous aerosol fractions based on light absorption, thermo-optical or laser-induced incandescence measurements. The quantities measured are defined based on the instrument and protocol used, with BC and EC related to optical and thermo-optical as well as chemical measurements, respectively. When BC is obtained by light absorption measurements it is referred to as mass equivalent black carbon (EBC; Petzold et al., 2013). In recent years, the Aethalometer, an online measurement technique of the aerosol light absorption at seven different wavelengths ranging from near-ultraviolet (N-UV) to near-infrared $(\mathrm{N}-$ IR), has become widely used, since it is rather inexpensive, portable, easy to operate and suitable for long-term measurements. Furthermore, multi-wavelength Aethalometer data may be used to derive the traffic and the wood-burning contributions to $\mathrm{EBC}\left(\mathrm{EBC}_{\mathrm{TR}}\right.$ and $\mathrm{EBC}_{\mathrm{WB}}$, respectively) taking advantage of the light absorption in the blue and $\mathrm{N}$ UV of aerosols from biomass-combustion likely due to coemitted organics, which is enhanced compared to aerosols from fossil sources (Sandradewi et al., 2008a). The so-called "Aethalometer model" assumes that light-absorbing particles only originate from vehicle and biomass-burning emissions, and uses absorption Ångström exponent $(\alpha)$ values specific to these sources to derive their contributions. Therefore, the source apportionment of EBC using the Aethalometer model is inherently dependent on the a priori assumed absorption Ångström exponents for traffic $\left(\alpha_{\mathrm{TR}}\right)$ and biomass burning $\left(\alpha_{\mathrm{WB}}\right)$, which are based on a few emission studies. $\alpha_{\mathrm{TR}}$ values cluster in a narrow range $(0.8-1.1)$, whereas a large range of $\alpha_{\mathrm{WB}}$ values ( 0.9 to 3.5) is reported (Schnaiter et al., 2003, 2005; Kirchstetter et al., 2004; Lewis et al., 2008; Saleh et al., 2013). Some studies also obtained $\alpha_{\mathrm{TR}}$ from ambient Aethalometer measurements by investigating the $\alpha$ values calculated from the ambient absorption coefficient $\left(b_{\mathrm{abs}}\right)$ values of the total light-absorbing aerosol during periods and locations that were only influenced by traffic emissions (e.g., in summer close to roads, Sandradewi et al., 2008b; Herich et al., 2011). It should be noted, however, that $\alpha$ values depend not only on different emission sources but also on the choice of wavelengths and different calculation procedures 
used, although deviations due to the latter are expected to be low (Moosmüller et al., 2011).

Another independent and more direct approach than the Aethalometer model to distinguish between modern (wood burning) and fossil (traffic) contributions is the radiocarbon analysis. Radiocarbon $\left({ }^{14} \mathrm{C}\right)$ is completely depleted in fossil fuel emissions $\left({ }^{14} \mathrm{C}\right.$ half-life $=5730$ years $)$ and can, therefore, be separated from non-fossil carbon sources, which have a similar ${ }^{14} \mathrm{C}$ signal as atmospheric carbon dioxide $\left(\mathrm{CO}_{2}\right.$; Currie, 2000; Szidat, 2009). Measuring ${ }^{14} \mathrm{C}$ in the EC fraction therefore directly enables the quantification of the wood-burning and fossil sources of EC. However, the ${ }^{14} \mathrm{C}$ analysis can only be performed on filter samples and is therefore limited in time resolution. Furthermore, such analysis is rather expensive and time consuming. The ${ }^{14} \mathrm{C}$ measurement in the EC fraction remains additionally challenging in contrast to TC (Szidat et al., 2013), since a clear physical separation between $\mathrm{OC}$ and EC is necessary to avoid interferences from $\mathrm{OC}$ in the ${ }^{14} \mathrm{C}$ signal. Nevertheless, recent developments and method adaptations from different groups show more consistent approaches and yield more robust ${ }^{14} \mathrm{C}$ results (Zhang et al., 2012; Bernardoni et al., 2013; Dusek et al., 2014).

Sandradewi et al. (2008a) first employed the Aethalometer model on winter data from a polluted Swiss Alpine valley and used ${ }^{14} \mathrm{C}$ measurements of the $\mathrm{EC}$ fraction to test the assumed $\alpha_{\mathrm{WB}}$ and $\alpha_{\mathrm{TR}}$. Based on this work, subsequent studies using the Aethalometer model employed similar $\alpha_{\mathrm{TR}}$ $(0.9-1.1)$ and $\alpha_{\mathrm{WB}}(1.8-2.2)$ values (e.g., Sandradewi et al., 2008b; Favez et al., 2010; Perron et al., 2010; Herich et al., 2011; Harrison et al., 2012, 2013; Crippa et al., 2013; Mohr et al., 2013), without further evaluations of these parameters using external data. Others compared the Aethalometer model outputs to apportionments using specific source tracers (Favez et al., 2010; Herich et al., 2014; Crilley et al., 2015). However, such approaches heavily rely on a priori assumed tracer-to-BC emission ratios, which are highly variable (Schmidl et al., 2008; El Haddad et al., 2011, 2013; Heringa et al., 2011), and as such are not suitable for the evaluation of the $\alpha_{\mathrm{TR}}$ and $\alpha_{\mathrm{WB}}$ values used in the Aethalometer model. Even though the Aethalometer model is widely used there are also studies (Harrison et al., 2013; Garg et al., 2016) that question the applicability of this model when other and/or additional combustion sources may contribute to the $\mathrm{BC}$ burden and combustion efficiencies are less well constrained.

In this study we present an evaluation of the Aethalometer model by comparing its outputs to ${ }^{14} \mathrm{C}$ results of the EC fraction in order to validate the choice of the absorption Ångström exponents for wood burning $\left(\alpha_{\mathrm{WB}}\right)$ and traffic emissions $\left(\alpha_{\mathrm{TR}}\right)$. To this end, we use ${ }^{14} \mathrm{C}$ and Aethalometer data from different campaigns across Switzerland, mostly from the winter season. The data set in this study $(n=101)$ is significantly larger than previously reported $(n=12$ and $n=18$ in Sandradewi et al., 2008a, b, respectively). In addi-

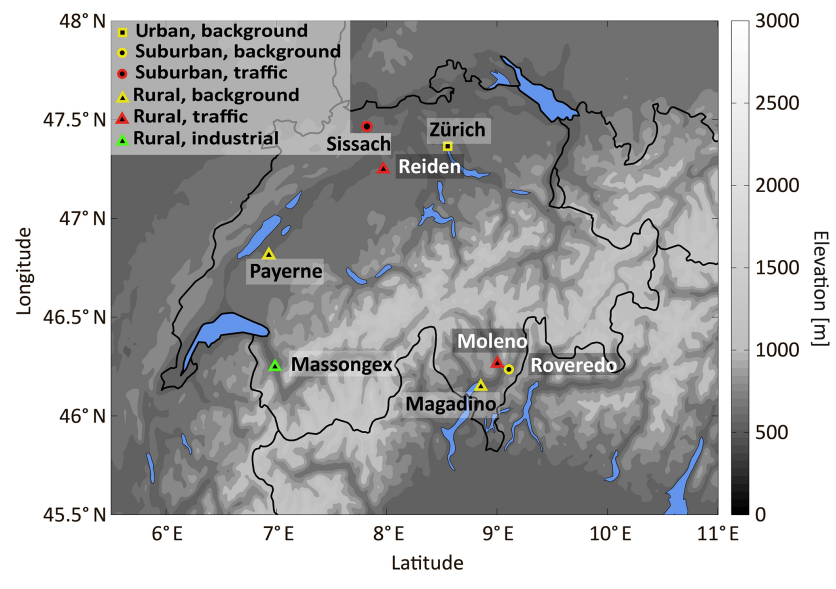

Figure 1. Location of the different stations in Switzerland investigated in this study.

tion, the data presented here were obtained at eight different stations in various area types with different source characteristics (e.g., urban, suburban, rural, Alpine valley, traffic, background, etc.) thereby enabling the evaluation of the performance and the uncertainties of the Aethalometer model in different environments.

\section{Materials and methods}

\subsection{Aerosol sampling}

Aerosol sampling presented in this study (see Table 1) was carried out at several stations of the Swiss National (NABEL) and Cantonal air pollution monitoring networks (EMPA, 2013; Cercl'Air, 2012). The stations ZUR, PAY, REI, and SIS are located north of the Alps, whereas MAG, ROV, and MOL are located south of the Alps and MAS is situated in the Rhone valley. The location of these stations in different areas allowed the sampling of a broad range of particles, with different characteristics ranging from urban to rural and from traffic to background. The exact locations of the stations are shown in Fig. 1 and the details and full names of the sites as well as the different campaigns carried out at these stations are listed in Table 1.

Filter sampling was conducted using quartz fiber filters (Pallflex 2500QAT-UP) and high-volume samplers (Digitel DHA-80, Switzerland) at a flow rate of $30 \mathrm{~m}^{3} \mathrm{~h}^{-1}$. The collection time as well as the size cut of the PM inlet varied between 16 and $40 \mathrm{~h}$ as well as $\mathrm{PM}_{1}$ and $\mathrm{PM}_{10}$, respectively, depending on the campaign (see Table 1). After sampling, filters were stored at $-20^{\circ} \mathrm{C}$ until analysis. Most of the results presented here $(n=69)$ were obtained on $\mathrm{PM}_{10}$ filters with a sampling time of $24 \mathrm{~h}$ from the 5 -year ${ }^{14} \mathrm{C}$ project Switzerland (Zotter et al., 2014). The samples from this campaign were collected on days with high $\mathrm{PM}_{10}$ concentrations (almost all of them exceeding the Swiss and EU daily limit of 
Table 1. List of all stations and their classification according to the Swiss Federal Office for the Environment (FOEN) and additional campaign details.

\begin{tabular}{|c|c|c|c|c|c|c|c|}
\hline Sampling site & Station code & Station type $\mathrm{e}^{5}$ & Campaign & Sampl. time & Size cut filter/AETH & Measurements & Reference \\
\hline \multirow[t]{3}{*}{ Roveredo } & \multirow[t]{3}{*}{ ROV } & \multirow[t]{3}{*}{ suburban/background } & Jan. 2005 & $16 \mathrm{~h}$ & $\mathrm{PM}_{10} / \mathrm{TSP}$ & \multirow{7}{*}{$\begin{array}{l}\text { levoglucosan } \\
\text { Aethalometer } \\
{ }^{14} \mathrm{C} \text { in } \mathrm{EC}\end{array}$} & Szidat et al. (2007) \\
\hline & & & Mar. 2005 & $16 \mathrm{~h}$ & $\mathrm{PM}_{1} / \mathrm{PM}_{2.5}$ & & Sandradewi et al. (2008a) \\
\hline & & & Dec. 2005 & $24 \mathrm{~h}$ & $\mathrm{PM}_{1} / \mathrm{PM}_{2.5}$ & & Sandradewi et al. (2008b) \\
\hline Moleno & MOL & rural/highway & Feb. 2005 & $16 \mathrm{~h}$ & $\mathrm{PM}_{10} / \mathrm{PM}_{10}$ & & Perron et al. (2010) \\
\hline Reiden & REI & rural/highway & Jan. \& Feb. 2005 & $24 \mathrm{~h}$ & $\mathrm{PM}_{10} / \mathrm{PM}_{1}$ & & \\
\hline Massongex & MAS & rural/industrial & Nov. \& Dec. 2005 & $24 \mathrm{~h}$ & $\mathrm{PM}_{10} / \mathrm{PM}_{1}$ & & \\
\hline Zürich & ZUR & urban/background & Jan. 2006 & $17 \mathrm{~h} / 40 \mathrm{~h}$ & $\mathrm{PM}_{1} / \mathrm{PM}_{1}$ & & \\
\hline Zürich & ZUR & urban/background & ${ }^{14} \mathrm{C}$ project & $24 \mathrm{~h}$ & $\mathrm{PM}_{10} / \mathrm{PM}_{2.5}$ & levoglucosan ${ }^{1}$ & Zotter et al. (2014) \\
\hline Magadino & MAG & rural/background & Switzerland & & & Aethalometer ${ }^{2}$ & Herich et al. (2011) \\
\hline Payerne & PAY & rural/background & (winter & & & ${ }^{14} \mathrm{C}$ in $\mathrm{EC}^{3}$ & Herich et al. (2014 and \\
\hline Sissach & SIS & suburban/traffic & 2007/2008-2011/2012) & & & $\mathrm{NO}_{x}^{4}$ & references therein) \\
\hline
\end{tabular}

${ }^{1}$ Levoglucosan was measured for ZUR, MAG, and PAY for the winter 2008 and 2009 during the ${ }^{14} \mathrm{C}$ project Switzerland (see Zotter et al., 2014, for more details). Additional data from these three stations were taken from Herich et al. (2011). ${ }^{2}$ Aethalometer measurements have been continuously performed at the NABEL stations MAG and PAY since 2008 and ZUR since 2009 . Data from these stations until January 2011 have been published in Herich et al. (2011) and data from 2011 and 2012 were provided by the NABEL network. An Aethalometer was additionally placed in SIS during winter 2010/2011 and 2011/2012. ${ }^{3}$ 14 C results of EC from all stations are presented in Zotter et al. (2014). ${ }^{4} \mathrm{NO}_{x}$ is continuously measured at the NABEL stations MAG, PAY, and ZUR using reference instrumentation with molybdenum converters according to valid European standards (see Herich et al., 2011; EMPA, 2013; and Zotter et al., 2014, for more details). ${ }^{5}$ Urban: station is located within a larger village or city and is surrounded by buildings with a high building density; suburban: building density in the immediate surrounding of the station is low and there is only little traffic in the area; rural: hardly any buildings in the surrounding of the station, larger streets and village/city several hundred meters or more away; traffic: station is located directly at a street with considerable amount of traffic; highway: station is located next to a highway; industrial: station is located in an industrial area; background: no large influence of direct emissions from sources in the near vicinity (e.g., traffic, industry or domestic).

$50 \mu \mathrm{g} \mathrm{m}^{-3}$ ). The period covers mainly the winter season at SIS, PAY, MAG, and ZUR and only few samples from spring and summer at ZUR were analyzed. Filter samples from earlier studies $(n=32)$ across Switzerland in 2005 at MOL, REI, MAS, and ROV as well as in 2006 at ZUR were only collected in winter during shorter campaigns ( $\sim 1$ month).

EBC has been continuously measured at the NABEL stations MAG (since 2008), PAY (since 2008) and ZUR (since 2009) using a 7-wavelength Aethalometer (MAGEE Scientific, model AE31; Herich et al., 2011; EMPA, 2013). The same type of instrument was also placed at SIS in the winters 2010/2011 and 2011/2012 during the ${ }^{14} \mathrm{C}$ project Switzerland and earlier campaigns in 2005 and 2006. In total 101 samples with parallel ${ }^{14} \mathrm{C}$ and Aethalometer measurements are available $(n=9,24,19,19,13,4,5,8$ for SIS, ZUR, MAG, PAY, ROV, MOL, REI and MAS, respectively).

\subsection{Aethalometer}

\subsubsection{Measurement principle}

The Aethalometer provides a real-time optical measurement of light-absorbing carbonaceous aerosols at seven wavelengths $(\lambda=370,470,520,590,660,880$, and $950 \mathrm{~nm}$; Hansen et al., 1984; Hansen, 2003). It measures the attenuation (ATN) of a light beam transmitted through a filter on which aerosols are continuously collected:

$\mathrm{ATN}=100 \cdot \ln \left(\frac{I_{0}}{I}\right)$,

where $I_{0}$ and $I$ denote the intensity of a light beam through an empty and particle-laden spot of a filter tape, respectively. The change in ATN over a certain time period $(t)$ is proportional to the attenuation coefficient $\left(b_{\mathrm{ATN}}\right)$ given a known flow rate $(Q)$ and spot size $(A)$ onto which particles are col- lected:

$b_{\mathrm{ATN}}=\frac{A}{Q} \cdot \frac{\Delta \mathrm{ATN}}{\Delta t}$.

Like all filter-based absorption techniques, the Aethalometer uses integration of the sample on the filter to increase the sensitivity of the measurement. Scattering by the filter fibers enhances absorption of the light by the aerosols collected on the filter tape. As the filter gets loaded by lightabsorbing aerosols and ATN increases, nonlinear loading effects become apparent (Liousse et al., 1993; Petzold et al., 1997; Bond et al., 1999; Park et al., 2010; Drinovec et al., 2015). To compensate for these effects, the algorithm developed by Weingartner et al. (2003) was used to derive the final absorption coefficient $\left(b_{\text {abs }}\right)$ :

$b_{\mathrm{abs}}(\lambda)=\frac{b_{\mathrm{ATN}}(\lambda)}{C_{\lambda} \cdot R\left(f_{\lambda}, \mathrm{ATN}_{\lambda}\right)}$

where $C_{\lambda}$ and $R\left(f_{\lambda}, \mathrm{ATN}_{\lambda}\right)$ are factors to compensate for multiple scattering of the filter fibers and the loading effect, respectively:

$R\left(f_{\lambda}, \mathrm{ATN}_{\lambda}\right)=\left(\frac{1}{f_{\lambda}}-1\right) \cdot \frac{\ln \left(\mathrm{ATN}_{\lambda}\right)-\ln (10)}{\ln (50)-\ln (10)}+1$.

In Eq. (4) $f_{\lambda}$ denotes the slope between the linear function $R\left(f_{\lambda}, \mathrm{ATN}_{\lambda}\right)$ vs. $\ln \left(\mathrm{ATN}_{\lambda}\right)$ and allows estimating the instrumental error that occurs when the shadowing effect is disregarded (Weingartner et al., 2003). This approach is routinely applied to the Aethalometer data from the NABEL stations using a single $C$ value of 2.14 for all wavelengths and wavelength-dependent $f$ values $(1.155,1.137,1.128$, 1.116, 1.103, 1.064, and 1.051 for 370, 470, 520, 590, 660, 880 , and $950 \mathrm{~nm}$, respectively) as proposed by Weingartner et al. (2003) and Sandradewi et al. (2008c), respectively. 
The same values were also used to compensate the data from SIS and the previous campaigns in Switzerland. Several other algorithms for the compensation of the Aethalometer data are available (Collaud Coen et al., 2010 and references therein) and some studies slightly adapted the Weingartner et al. (2003) approach (Sandradewi et al., 2008c; Favez et al., 2010; Mohr et al., 2013; Segura et al., 2014). It should be noted that these different compensation algorithms might yield slightly different $b_{\text {abs }}(\lambda)$. However, the comparison of these approaches or the improvement of the compensation methodology used is beyond the scope of this study. Also the recently developed dual spot Aethalometer (AE33, Drinovec et al., 2015) allows for an improved and time-dependent loading compensation.

The compensated $b_{\text {abs }}$ is then converted into a EBC mass using the mass absorption cross section (MAC):

$\mathrm{BC}=\frac{b_{\mathrm{abs}}(\lambda)}{\operatorname{MAC}(\lambda)}$

Usually nominal MAC values are used, to directly infer EBC mass from the non-compensated $b_{\mathrm{ATN}}$. These MAC values can be calculated from the parameters furnished by the Aethalometer manufacturer (Hansen, 2003) or are provided in the literature (e.g., Bond et al., 2013, and references therein) and include a $C$ value. Here MAC values are obtained empirically by comparing $b_{\text {abs }}$ with simultaneous measurements of EC from thermo-optical methods (e.g., Moosmüller et al., 2001; Bond et al., 2013 and references therein), and the EBC concentration is assumed to be identical to the EC concentration. From Eqs. (3) and (5) it is evident that empirically derived MAC values for absorption photometers strongly depend on the assumed $C$ value. Different $C$ values were previously empirically derived from instrumental comparisons and used to determine the absorption coefficient from Aethalometer measurements (e.g., Collaud Coen et al., 2010; Segura et al., 2014; Crilley et al., 2015). The separation of the $C$ value and the MAC is therefore relative to the methods used, and empirically determined MAC values using Aethalometers should always be reported together with the applied $C$ values $(C=2.14$ in our case).

\subsubsection{Source apportionment using Aethalometer data}

The spectral dependence of the absorption is described by the power law $b_{\text {abs }}(\lambda) \sim \lambda^{-\alpha}$ (Moosmüller et al., 2011), where $\alpha$ is the absorption Ångström exponent and consequently for a wavelength pair the following relation can be derived:

$\frac{b_{\mathrm{abs}}\left(\lambda_{1}\right)}{b_{\mathrm{abs}}\left(\lambda_{2}\right)}=\left(\frac{\lambda_{1}}{\lambda_{2}}\right)^{-\alpha}$.

$\mathrm{BC}$ is a strong broadband absorber over the entire visible wavelength range (N-UV to N-IR) with only a weak spectral dependence ( $\alpha$ for $\mathrm{BC} \sim 1$ ). Traffic emissions mainly contain $\mathrm{BC}$ and basically no other light-absorbing compounds and consequently $\alpha$ for traffic emissions $\left(\alpha_{\mathrm{TR}}\right) \sim 1$ (Bond et al., 2013; Kirchstetter et al., 2004; Schnaiter et al., 2003, 2005). Biomass-burning aerosols, on the other hand, contain additionally to BC a substantial fraction of light-absorbing organic substances which strongly enhance the light absorption in the N-UV and blue part of the spectrum and have no contribution in the N-IR wavelength range resulting in an $\alpha$ for biomass-burning emissions $\left(\alpha_{\mathrm{WB}}\right)$ that is larger than $\alpha_{\text {TR }}$. Based on this, Sandradewi et al. (2008a) developed a two-component model to apportion $b_{\text {abs }}$ measured with the Aethalometer at different wavelengths into a wood-burning (WB) and a traffic (TR) contribution assuming that the total $b_{\text {abs }}$ is only influenced by these two sources:

$b_{\text {abs,total }}(\lambda)=b_{\text {abs,TR }}(\lambda)+b_{\text {abs, WB }}(\lambda)$.

This assumption is valid for Switzerland and other Alpine regions in Europe, especially in winter, where emissions from other sources are negligible. Coal burning is not used in these areas (Eurostat, 2017) and biogenic secondary organic aerosol (SOA) is mostly absorbing in the UV range (Romonosky et al., 2016) not covered by wavelengths used in the Aethalometer (especially given that we recommend the use of the absorption at $470 \mathrm{~nm}$ rather than at $370 \mathrm{~nm}$; see Sect. 3.2.4). Mineral dust can usually be neglected in this region (contribution to total $\mathrm{PM}<\sim 10 \%$; Gianini et al., 2012), and special events possibly influencing the absorption at Aethalometer wavelengths $470-590 \mathrm{~nm}$ can be identified due to a drop of the absorption Ångström exponent clearly below one during such events (Collaud Coen et al., 2004). Using Eqs. (6)-(7) and the measured $b_{\text {abs }}$ at two different wavelengths, a traffic and wood-burning contribution can be apportioned using the following equations:

$$
\begin{aligned}
& \frac{b_{\mathrm{abs}, \mathrm{TR}}\left(\lambda_{1}\right)}{b_{\mathrm{abs}, \mathrm{TR}}\left(\lambda_{2}\right)}=\left(\frac{\lambda_{1}}{\lambda_{2}}\right)^{-\alpha_{\mathrm{TR}}}, \\
& \frac{b_{\mathrm{abs}, \mathrm{WB}}\left(\lambda_{1}\right)}{b_{\mathrm{abs}, \mathrm{WB}}\left(\lambda_{2}\right)}=\left(\frac{\lambda_{1}}{\lambda_{2}}\right)^{-\alpha_{\mathrm{WB}}}, \\
& b_{\mathrm{abs}, \mathrm{WB}}\left(\lambda_{2}\right)=\frac{b_{\mathrm{abs}}\left(\lambda_{1}\right)-b_{\mathrm{abs}}\left(\lambda_{2}\right) \cdot\left(\frac{\lambda_{1}}{\lambda_{2}}\right)^{-\alpha_{\mathrm{TR}}}}{\left(\frac{\lambda_{1}}{\lambda_{2}}\right)^{-\alpha_{\mathrm{WB}}}-\left(\frac{\lambda_{1}}{\lambda_{2}}\right)^{-\alpha_{\mathrm{TR}}}}, \\
& b_{\mathrm{abs}, \mathrm{TR}}\left(\lambda_{2}\right)=\frac{b_{\mathrm{abs}}\left(\lambda_{1}\right)-b_{\mathrm{abs}}\left(\lambda_{2}\right) \cdot\left(\frac{\lambda_{1}}{\lambda_{2}}\right)^{-\alpha_{\mathrm{WB}}}}{\left(\frac{\lambda_{1}}{\lambda_{2}}\right)^{-\alpha_{\mathrm{TR}}}-\left(\frac{\lambda_{1}}{\lambda_{2}}\right)^{-\alpha_{\mathrm{WB}}}} .
\end{aligned}
$$

The contributions of wood-burning and traffic to total EBC $\left(\mathrm{EBC}_{\mathrm{WB}}\right.$ and $\left.\mathrm{EBC}_{\mathrm{TR}}\right)$ are then derived via the corresponding MAC values ( $\mathrm{MAC}_{\mathrm{WB}}$ and $\mathrm{MAC}_{\mathrm{TR}}$, respectively):

$$
\begin{aligned}
\mathrm{EBC}_{\text {tot }} & =\mathrm{EBC}_{\mathrm{WB}}+\mathrm{EBC}_{\mathrm{TR}} \\
& =\frac{b_{\mathrm{abs}, \mathrm{TR}}\left(\lambda_{2}\right)}{\operatorname{MAC}_{\mathrm{TR}}\left(\lambda_{2}\right)}+\frac{b_{\mathrm{abs}, \mathrm{WB}}\left(\lambda_{2}\right)}{\operatorname{MAC}_{\mathrm{WB}}\left(\lambda_{2}\right)} .
\end{aligned}
$$

Consequently the ratio $\mathrm{EBC}_{\mathrm{TR}}$ to total $\mathrm{EBC}\left(\mathrm{EBC}_{\mathrm{TOT}}\right)$ can be derived from the measured ratio $b_{\mathrm{abs}}\left(\lambda_{1}\right)$ to $b_{\mathrm{abs}}\left(\lambda_{2}\right)$ and 
assuming the ratio $\operatorname{MAC}_{\mathrm{TR}}\left(\lambda_{2}\right)$ to $\operatorname{MAC}_{\mathrm{WB}}\left(\lambda_{2}\right)$ :

$$
\begin{aligned}
\frac{\mathrm{EBC}_{\mathrm{TR}}}{\mathrm{EBC}_{\mathrm{tot}}} & = \\
& \frac{1}{1-\frac{\mathrm{MAC}_{\mathrm{TR}}\left(\lambda_{2}\right)}{\mathrm{MAC}_{\mathrm{WB}}\left(\lambda_{2}\right)} \cdot \frac{1-\frac{b_{\text {abs }}\left(\lambda_{2}\right)}{b_{\mathrm{abb}}\left(\lambda_{1}\right)} \cdot\left(\frac{\lambda_{1}}{\lambda_{2}}\right)^{-\alpha_{\mathrm{TR}}}}{1-\frac{b_{\text {abs }}\left(\lambda_{2}\right)}{b_{\mathrm{abs}}\left(\lambda_{1}\right)} \cdot\left(\frac{\lambda_{1}}{\lambda_{2}}\right)^{-\alpha_{\mathrm{WB}}}}} .
\end{aligned}
$$

Using Eqs. (3)-(6), Eq. (13) can be written as

$$
\begin{aligned}
& \frac{\mathrm{EBC}_{\mathrm{TR}}}{\mathrm{EBC}_{\mathrm{to}}}
\end{aligned}
$$

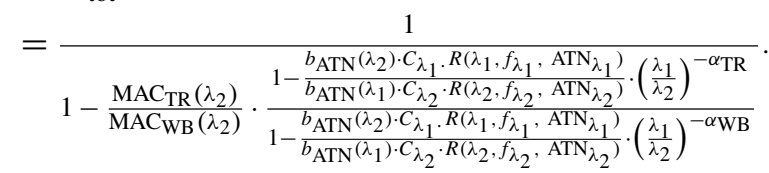

$\lambda_{2}$ has to be a wavelength in the N-IR range, where EBC is the only light absorber, whereas $\lambda_{1}$ should be taken from the $\mathrm{N}-\mathrm{UV}$ range where also organics contribute to the light absorption. In this model $\alpha_{\mathrm{WB}}$ and $\alpha_{\mathrm{TR}}$ have to be assumed a priori or determined comparing the contributions of $\mathrm{EBC}_{\mathrm{TR}}$ and $\mathrm{EBC}_{\mathrm{WB}}$ to other techniques which apportion $\mathrm{BC}$ or EC into those two sources (e.g., ${ }^{14} \mathrm{C}$ measurements). Additional uncertainties may arise from the compensation factors applied to the attenuation coefficients. In this study, a fixed $C_{\lambda}$ value was used for the multi-scattering correction (Sect. 2.2.1) and thus the ratio $C_{\lambda, 1} / C_{\lambda, 2}$ becomes unity in Eq. (14). This is justified and introduces very little uncertainty, as the wavelength dependence of the $f$ and $C$ values across the range $\lambda=470-950 \mathrm{~nm}$ was reported to be less than 10 and $12 \%$, respectively, for the Aethalometer model AE31 (Weingartner et al., 2003; Sandradewi et al., 2008c; Segura et al., 2014). If data from other photometer models, which exhibit a wavelength dependence of the $C$ value, are used for the source apportionment, the correct ratio $C_{\lambda, 1} / C_{\lambda, 2}$ must be used in Eq. (14) to ensure consistency of the Aethalometer model parameters. The loading compensation factor $R\left(f_{\lambda}\right.$, $\operatorname{ATN}_{\lambda}$ ) depends on wavelength, even if $f(\lambda)$ is independent of the wavelength, since the ATN depends considerably on the wavelength. Nevertheless, uncertainties in the $\mathrm{EBC}_{\mathrm{TR}}$ to EBC ratio associated with the filter-loading compensation can be kept small by carefully determining the $f$ values, following the approach in Weingartner et al. (2003) or Sandradewi et al. (2008c). The Aethalometer AE33 measures the compensation parameters and therefore the compensation is performed on-line. The precision of this compensation can be checked using the EBC(ATN) or $b_{\text {abs }}(\mathrm{ATN})$ analysis (Drinovec et al., 2015). It should be noted that the calculation of the $\mathrm{EBC}_{\mathrm{TR}}$ to $\mathrm{EBC}$ ratio (Eq. 13) might not only be sensitive to the choice of compensation parameters but also on the choice of compensation algorithm. However, large uncertainties of the $\mathrm{EBC}_{\mathrm{TR}}$ to $\mathrm{EBC}$ ratio due to the use of different Aethalometer data compensation algorithms are not expected since in Eqs. (13) and (14) only fractional contributions of $b_{\text {abs }}(\lambda)$ or $b_{\text {ATN }}(\lambda)$ are used. Therefore, only differences in the wavelength dependency of the compensation parameters in different compensation methods would slightly affect the determination of $\mathrm{EBC}_{\mathrm{TR}} / \mathrm{EBC}$. An investigation of such effects is beyond the scope of this study; however, future work should be carried out exploring possible influences of different compensation methodologies on $\mathrm{EBC}_{\mathrm{TR}}$ / $\mathrm{EBC}$. A detailed comparison of the different Aethalometer compensation algorithms can be found in Collaud Coen et al. (2010) and only an overall assessment of the methodology used will be discussed below.

Sandradewi et al. (2008a) and subsequent studies that used the Aethalometer model utilized the same MAC for traffic $\left(\mathrm{MAC}_{\mathrm{TR}}\right)$ and wood burning $\left(\mathrm{MAC}_{\mathrm{WB}}\right)$ emissions at the $\mathrm{N}-$ IR wavelength, based on the fact that MAC values for freshly generated EBC were previously found to fall within a relatively narrow range (Bond and Bergstrom, 2006 and references therein). However, MAC values depend on particle size, morphology, and mixing state and thus different values for biomass-burning and traffic emissions may be possible. Therefore, we assess the ratio of $\mathrm{MAC}_{\mathrm{TR}}$ to $\mathrm{MAC}_{\mathrm{WB}}$ for our data set in Sects. 3.1 and 3.2.1.

Sandradewi et al. (2008a) and many other studies used 470 and $950 \mathrm{~nm}$ as N-UV and N-IR wavelengths, respectively. However, also other combinations of wavelengths have been used (e.g., 370 and 880, or 470 and $880 \mathrm{~nm}$; see Perron et al., 2010; Herich et al., 2011; and Fuller et al., 2014), especially in studies that performed Aethalometer measurements with the two-wavelength instrument $(370$ and $880 \mathrm{~nm}$, model AE22, Magee Scientific). Therefore, we will also investigate the sensitivity of the Aethalometer model using different wavelength combinations.

\subsection{Radiocarbon analysis}

\subsubsection{Separation of the carbonaceous particle fractions}

Two different methods to isolate $\mathrm{EC}$ for the ${ }^{14} \mathrm{C}$ analysis were used. For the samples from the ${ }^{14} \mathrm{C}$ project Switzerland, the Swiss_4S protocol was applied for the EC isolation using a Sunset OC / EC analyzer as described by Zhang et al. (2012). This approach is optimized such that biases in the ${ }^{14} \mathrm{C}$ result of $\mathrm{EC}$ due to OC charring or losses of the least refractory EC during the OC removal are minimized. In brief, to minimize positive artifacts from OC charring, water-soluble OC (WSOC) is first eliminated by a water extraction and the remaining water-insoluble OC (WINSOC) is then removed using the Sunset analyzer by a thermal treatment in three steps: (1) $375^{\circ} \mathrm{C}$ for $150 \mathrm{~s}$ in pure oxygen $\left(\mathrm{O}_{2}\right)$; (2) $475^{\circ} \mathrm{C}$ for $180 \mathrm{~s}$ in $\mathrm{O}_{2}$; (3) $450^{\circ} \mathrm{C}$ for $180 \mathrm{~s}$ followed by $180 \mathrm{~s}$ at $650^{\circ} \mathrm{C}$ in helium. Finally, in a fourth step, EC is isolated by the combustion of the remaining carbonaceous material at $760^{\circ} \mathrm{C}$ for $150 \mathrm{~s}$ in $\mathrm{O}_{2}$. The evolving $\mathrm{CO}_{2}$ is separated from interfering gaseous products, cryo-trapped and sealed in glass ampoules for ${ }^{14} \mathrm{C}$ measurements. By using the Sunset analyzer, which 
monitors the transmission of light through the filter with a laser during the combustion, the quantification of $\mathrm{OC}$ charring and EC losses before the fourth step is achieved. For the samples of the ${ }^{14} \mathrm{C}$ project Switzerland, charred OC only contributed $\sim 5 \%$ to EC recovered in the fourth step and on average $74 \pm 11 \%$ of the $\mathrm{EC}$ was recovered for the ${ }^{14} \mathrm{C}$ measurement. Charring OC of a given thermal step is quantified as the difference of the maximum ATN and the initial ATN normalized to the initial ATN. The EC recovery is related to the loss of EC during the first three steps and is defined as the ratio between the ATN of the laser signal through the filter before step 4 (EC step) and the initial ATN before the thermal treatment before the first step (Zhang et al., 2012).

$\mathrm{EC}$ from samples collected during the campaigns in ROV, MOL, MAS, REI, ZUR in 2005 and 2006 was isolated for the ${ }^{14} \mathrm{C}$ analysis using the THEODORE system and the approach described by Szidat et al. (2004). In brief, after removal of WSOC by water extraction, WINSOC was evaporated during $4 \mathrm{~h}$ in a muffle furnace in air at $375^{\circ} \mathrm{C}$. EC was finally combusted in the THEODORE system at $640^{\circ} \mathrm{C}$ for $10 \mathrm{~min}$ with $\mathrm{O}_{2}$. The evolving $\mathrm{CO}_{2}$ was recovered in the same manner as described above. The EC recovery for these samples was estimated by Zhang et al. (2012) and was on average $60 \pm 12 \%$. The ${ }^{14} \mathrm{C}$ results of EC were corrected to $100 \%$ EC recovery (see Sect. 2.4.3 below) and results obtained with the THEODORE and the Swiss_4S method were previously found to agree within the uncertainties (see Zhang et al., 2012).

\subsubsection{Radiocarbon measurement}

The analysis of the ${ }^{14} \mathrm{C}$ content in the $\mathrm{CO}_{2}$ from the separated EC fraction collected as described above was carried out with the MIni radio CArbon DAting System, MICADAS (Synal et al., 2007) at the Swiss Federal Institute of Technology (ETH) Zurich and the Laboratory for the Analysis of Radiocarbon with AMS (LARA), University of Bern (Szidat et al., 2014) using a gas ion source (Ruff et al., 2010; Wacker et al., 2013). The results of the ${ }^{14} \mathrm{C}$ measurement are presented as fraction of modern $\left(f_{\mathrm{M}}\right)$ denoting the ${ }^{14} \mathrm{C} /{ }^{12} \mathrm{C}$ content of the sample related that of the reference year 1950 (Stuiver and Polach, 1977). The $f_{M}$ values are corrected for $\delta^{13} \mathrm{C}$ fractionation and for ${ }^{14} \mathrm{C}$ decay between 1950 and the year of measurement (Wacker et al., 2010). The $f_{\mathrm{M}}$ measurement uncertainty for the EC samples from the ${ }^{14} \mathrm{C}$ project Switzerland and ROV, MOL, MAS, REI, ZUR from 2005 and 2006 is $\sim 2 \%$ (Zotter et al., 2014) and $\sim 3 \%$ respectively (Zhang et al., 2012).

\subsubsection{Determination of the non-fossil fraction of EC}

As shown above (see Sect. 2.2), on average only $74 \pm 11$ and $60 \pm 12 \%$ of the total EC (EC yield) was isolated for the ${ }^{14} \mathrm{C}$ measurement of the samples from the ${ }^{14} \mathrm{C}$ project Switzerland and ROV, MOL, MAS, REI, ZUR from 2005 and 2006, respectively. However, Zhang et al. (2012) showed that $f_{\mathrm{M}}$ values are lower for lower EC yields suggesting that the EC that is removed before the fourth step (the step in which EC is recovered for the ${ }^{14} \mathrm{C}$ measurement), is mainly from biomass burning due to its lower thermal stability (Zhang et al., 2012). Therefore, an extrapolation of the measured $\mathrm{EC} f_{\mathrm{M}}$ values to $100 \%$ EC yield was applied to account for this underestimation of $f_{\mathrm{M}}$ (Zhang et al., 2012). This method was applied to all samples discussed here, and the detailed description of the procedure used for the samples from the ${ }^{14} \mathrm{C}$ project Switzerland and ROV, MOL, MAS, REI, ZUR from 2005 and 2006 can be found in Zotter et al. (2014) and Zhang et al. (2012), respectively.

The $f_{\mathrm{M}}$ of contemporary carbon including biogenic sources and biomass burning ( $f_{\mathrm{M} \text {,bio }}$ and $f_{\mathrm{M}, \mathrm{WB}}$, respectively) is characterized by values of 1 whereas $f_{M}$ is equal to 0 for fossil sources due to the decay of ${ }^{14} \mathrm{C}$ with a half-life of 5730 years. Due to the nuclear weapon tests in the 1950s and 1960s, however, the atmospheric ${ }^{14} \mathrm{C}$ content increased and $f_{\mathrm{M}}$ exhibits values $>1$ (Levin et al., 2010). Therefore, $f_{\mathrm{M}}$ values for $\mathrm{EC}$ were converted into non-fossil fractions $\left(f_{\mathrm{NF}, \mathrm{EC}}\right.$; Szidat et al., 2006$)$ using a reference value. Since biomass burning is the only non-fossil source of EC (neglecting possible small contributions from bio-fuels) this reference value is equal to $f_{\mathrm{M} \text {,WB }}$ and was estimated using a tree-growth model as described in Mohn et al. (2008) including $10,20,40,70$, and 85-year old trees with weight fractions of $0.2,0.2,0.4,0.1$, and 0.1 , respectively, harvested 3 years before aerosol sampling. Values of 1.140, 1.135, 1.127, $1.123,1.119,1.114$, and 1.106 were calculated and consequently used to correct the $f_{\mathrm{M}}$ values extrapolated to $100 \%$ EC yield from samples collected in 2005, 2006, 2008, 2009, 2010, 2011, and 2012, respectively. The final uncertainties for $f_{\mathrm{NF}, \mathrm{EC}}\left(\sim 5\right.$ and $\sim 6 \%$ for samples from the ${ }^{14} \mathrm{C}$ project Switzerland and ROV, MOL, MAS, REI, ZUR from 2005 and 2006, respectively) are derived from an error propagation and include all the individual uncertainties of $f_{\mathrm{M}}$ (measurement uncertainty, extrapolation to $100 \%$ EC yield) and $f_{\mathrm{M}, \mathrm{WB}}$ (Zotter et al., 2014).

\subsection{Elemental carbon measurement}

The EC concentrations on samples from the ${ }^{14} \mathrm{C}$ project Switzerland (see Table 1) were measured using a thermooptical OC / EC analyzer (Model 4L, Sunset Laboratory Inc., USA), equipped with a non-dispersive infrared (NDIR) detector following the thermal-optical transmittance protocol (TOT) EUSAAR2 (Cavalli et al., 2010). EC concentrations from the campaigns in ROV, MOL, MAS, REI, ZUR in 2005 and 2006 (see Table 1) are not included for the MAC calculations, since in earlier campaigns they were not measured or obtained with a different TOT protocol. We assigned a high uncertainty of $25 \%$ for all measured EC concentrations to account for possible differences between different TOT protocols (Schmid et al., 2001). It should be noted that only the 
MAC determination is affected by the uncertainty of the EC concentrations whereas the evaluation of the choice of $\alpha_{\mathrm{WB}}$ and $\alpha_{\mathrm{TR}}$ using the fossil fraction of EC is influenced by the combined uncertainty of the ${ }^{14} \mathrm{C}$ measurement of EC, the extrapolation of $f_{\mathrm{M} \text {,EC }}$ to $100 \%$ EC yield and the bomb peak correction which was on average only 5-6\% (see Sect. 2.3). No EC was detected on blank filters and consequently no blank correction was necessary (see also Zotter et al., 2014).

\subsection{Additional data}

Nitrogen oxides $\left(\mathrm{NO}_{x}\right)$ are routinely measured at the NABEL stations ZUR, MAG, and PAY using reference instrumentation with molybdenum converters according to valid European standards (EMPA, 2013). Since no large sources of $\mathrm{NO}_{x}$ (e.g., fossil fuel power plants) are present in Switzerland besides traffic, $\mathrm{NO}_{x}$ will be used here for the comparison with $\mathrm{EBC}_{\mathrm{TR}}$ (see Sect. 3.3 below).

Levoglucosan, a thermal degradation product of cellulose and thus a tracer for primary emissions of organic aerosol from biomass burning and often used to estimate OC mass from this source (Gelencsér et al., 2007), was also measured on 52 samples presented in this study. A description of the measurement details can be found in the corresponding references as listed in Table 1. Levoglucosan data are available for most of the samples from winter 2005 and 2006 from ROV, MOL, REI, MAS, and ZUR $(n=27)$ as well as from the winter 2008/2009 for ZUR, MAG, and PAY $(n=8)$ from the ${ }^{14} \mathrm{C}$ project Switzerland (see Zotter et al., 2014). In addition, data from these three stations $(n=17)$ with parallel Aethalometer measurements available were also taken from Herich et al. (2011). Levoglucosan data will be used here for the comparison with $\mathrm{EBC}_{\mathrm{WB}}$ (see Sect. 3.3 below). As photochemical degradation of levoglucosan was previously observed under summertime conditions (Kessler et al., 2010; Hennigan et al., 2011), spring and summer levoglucosan data from ZUR are not used here.

\section{Results and discussion}

\subsection{MAC determination}

MAC values are determined empirically by comparing $b_{\text {abs }}$ with EC thermo-optical measurements (see Fig. 2a). $b_{\text {abs }}$ at $880 \mathrm{~nm}$ and EC are strongly correlated $(r=0.86)$ and the geometric mean of the MAC at $880 \mathrm{~nm}$ was found to be $11.8 \mathrm{~m}^{2} \mathrm{~g}^{-1}\left(9.2-15.1 \mathrm{~m}^{2} \mathrm{~g}^{-1}\right)$, similar to values obtained in Herich et al. (2011) for ZUR $\left(10.0 \mathrm{~m}^{2} \mathrm{~g}^{-1}\right)$, PAY $\left(13.2 \mathrm{~m}^{2} \mathrm{~g}^{-1}\right)$, and MAG $\left(9.9 \mathrm{~m}^{2} \mathrm{~g}^{-1}\right)$ for a 2-year data set (note that the MAC values reported in this study as well as that by Herich et al. (2011) both apply for EC mass based on the thermal-optical transmittance protocol EUSAAR2 and absorption coefficients inferred from Aethalometer AE31 data with assuming a $C$ value of 2.14). No systematic yearto-year or station-to-station variations in the MAC values at
$880 \mathrm{~nm}$ are observed. While the MAC values determined at SIS are lower on average, they remain within the previously reported range, and given the relatively modest number of samples, this observation cannot be generalized. It should be noted that MAC values depend on the aerosol mixing state, size, and morphology (see, e.g., Bond and Bergstrom, 2006), and empirically derived MAC values also depend on the limitations of the measurement techniques used to determine $b_{\text {abs. }}$ The results of our study would translate to $\sim 9.7-10.0 \mathrm{~m}^{2} \mathrm{~g}^{-1}$ at $637 \mathrm{~nm}$ when recalculating our MAC values from a wavelength of 880 to $637 \mathrm{~nm}$ with an absorption Angström exponent of $0.9-1.0$ and if a $C$ value of 3.5 instead of 2.14 was assumed. This is in good agreement with the average MAC value of $10.0 \mathrm{~m}^{2} \mathrm{~g}^{-1}$ at $637 \mathrm{~nm}$ reported by Zanatta et al. (2016) for nine European background sites, who also used the EUSAAR2 protocol for EC mass and either multi-angle absorption photometers, particle soot absorption photometers, or Aethalometers with assuming $C=3.5$ for the absorption coefficient. Deviations from other previously reported MAC values at similar wavelengths $\left(-5-26 \mathrm{~m}^{2} \mathrm{~g}^{-1}\right.$, Liousse et al., 1993; Bond and Bergstrom, 2006; Genberg et al., 2013) can be due to different methods used to determine EC and the absorption coefficient and/or possible differences in $\mathrm{BC}$ size and mixing state.

Only few studies attempted the empirical determination of MAC values for biomass-burning and traffic EBC emissions using ambient measurements (e.g., Laborde et al., 2013; Bond et al., 2013 and references therein). Since the ratio of $\mathrm{MAC}_{\mathrm{TR}}$ to $\mathrm{MAC}_{\mathrm{WB}}$ at the N-IR wavelength is needed in the Aethalometer model (see Eq. 13), it is important to assess possible differences between $\mathrm{MAC}_{\mathrm{TR}}$ and $\mathrm{MAC}_{\mathrm{WB}}$. Sandradewi et al. (2008a) and all other studies that applied the Aethalometer model assumed, implicitly or explicitly, a $M A C_{T R}$ to $M A C_{W B}$ ratio of unity at $880 \mathrm{~nm}$. Having an independent measurement for the relative contributions of traffic and wood-burning to total EC from the ${ }^{14} \mathrm{C}$ measurements allows us to test this assumption by plotting the MAC values at $880 \mathrm{~nm}$ against the corresponding relative traffic contribution to $\mathrm{EC}\left(\mathrm{EC}_{\mathrm{F}} / \mathrm{EC}\right)$ obtained with the ${ }^{14} \mathrm{C}$ measurements (see Fig. 2b). No correlation between the two parameters was found, indicating that it is justified to simplify the Aethalometer model (Eq. 12) and set the ratio of $\mathrm{MAC}_{\mathrm{TR}}$ to $\mathrm{MAC}_{\mathrm{WB}}$ at the N-IR wavelength to unity. This is in agreement with Herich et al. (2011) who did not find differences in MAC for the stations ZUR, MAG and PAY for a 2-year data set between summer and winter, where there is a large seasonality in the relative wood-burning contribution. The variability in Fig. $2 b$ is due to day-to-day and station-to-station variability but could to some degree also originate from different size cuts $\left(\mathrm{PM}_{10}\right.$ or $\mathrm{PM}_{1}$ and $\left.\mathrm{PM}_{2.5}\right)$ of the filter samplers and Aethalometer measurements for some campaigns (see Table 1). Alternatively, the ratio of $\mathrm{MAC}_{\mathrm{TR}}$ to $\mathrm{MAC}_{\mathrm{WB}}$ at the N-IR wavelength can be used as a third free parameter, besides $\alpha_{\mathrm{TR}}$ and $\alpha_{\mathrm{WB}}$, when fitting the Aethalometer model (Eq. 12) against a data set of independent $\mathrm{EC}_{\mathrm{F}} / \mathrm{EC}$ mea- 

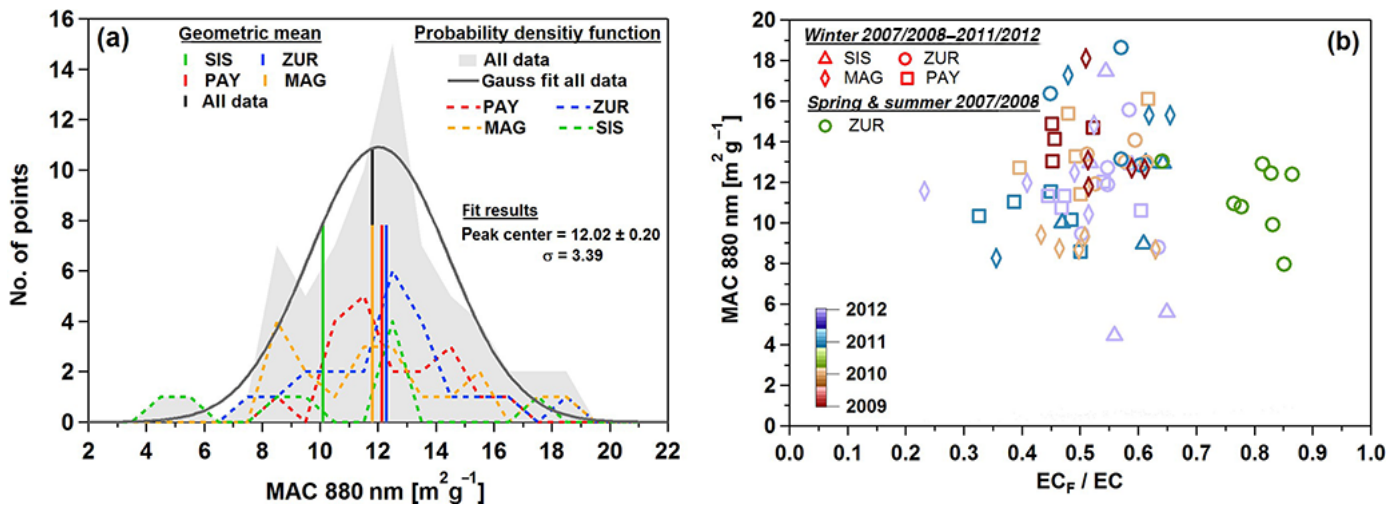

Figure 2. Distribution of MAC values of EBC at $880 \mathrm{~nm}$ (a) and comparison with the fossil fraction of EC (ECF / EC) determined with the ${ }^{14} \mathrm{C}$ analysis (b). MAC values were determined assuming a $C$ value of 2.14 for the Aethalometer and the EUSAAR-2 thermal optical transmission protocol was used for EC mass measurement. Only data from the ${ }^{14} \mathrm{C}$ project Switzerland are included, since in earlier campaigns EC concentrations were not determined or measured with the same TOT protocol.

surements. We tested this for the data set of this study and obtained a $\mathrm{MAC}_{\mathrm{TR}}$ to $\mathrm{MAC}_{\mathrm{WB}}$ ratio of 0.97 , which confirms the finding of Fig. 2b. Therefore, in the following we will use a fixed $\mathrm{MAC}_{\mathrm{TR}}$ to $\mathrm{MAC}_{\mathrm{WB}}$ ratio of 1 in the Aethalometer model.

\subsection{Application and evaluation of the Aethalometer model}

\subsubsection{Best $\alpha_{\mathrm{TR}}$ and $\alpha_{\mathrm{WB}}$ pair, and analysis of uncertainties and biases}

Independent measurements of the contribution of wood burning and traffic to $\mathrm{BC}$ (or EC) are often not available; therefore in most studies a single $\alpha_{\mathrm{TR}}$ and $\alpha_{\mathrm{WB}}$ pair is usually used in the Aethalometer model, derived from previous work. However, $\alpha_{\mathrm{WB}}$ and $\alpha_{\mathrm{TR}}$ may be highly variable, depending on the combustion conditions and efficiency, fuel type and aerosol aging (Lack et al., 2013; Saleh et al., 2013, 2014; Zhong and Jang, 2014; Sharpless et al., 2014; Kirchstetter et al., 2004; Bond and Bergstrom, 2006 and references therein; Herich et al., 2011; Garg et al., 2016). In this section we use $\mathrm{EC}_{\mathrm{F}} / \mathrm{EC}$ values from ${ }^{14} \mathrm{C}$ measurements to determine the best combination of $\alpha_{\mathrm{TR}}$ and $\alpha_{\mathrm{WB}}$ and assess the performance of the Aethalometer model using this single pair of $\alpha$ values. In practice, the best pair of $\alpha$ values is determined by fitting Eq. (13) against $\mathrm{EC}_{\mathrm{F}} / \mathrm{EC}$ from the ${ }^{14} \mathrm{C}$ analyses using the ratio $b_{\mathrm{abs}, 470} / b_{\mathrm{abs}, 950}$ from the Aethalometer as independent variable (and assuming $\mathrm{MAC}_{\mathrm{TR}, 950} / \mathrm{MAC}_{\mathrm{WB}, 950}=1$, as justified in Sect. 3.1). We use a least-square fitting weighted by the inverse number of data points in $\mathrm{EC}_{\mathrm{F}} / \mathrm{EC}$ bins of 0.1 as most of the data presented in this study fall within a range of $\mathrm{EC}_{\mathrm{F}} / \mathrm{EC}=0.4$ 0.6. The absorption Ångström exponents $\alpha_{\mathrm{TR}}$ and $\alpha_{\mathrm{WB}}$ that fit best our data were found to be 0.90 and 1.68 , respectively. The same $\alpha$ values were obtained when $\mathrm{MAC}_{\mathrm{TR}} / \mathrm{MAC}_{\mathrm{WB}}$ was included as a third fitting parameter, because the best-fit
MAC ratio is 0.97 , which is virtually equal to unity (see also Sect. 3.1).

$\mathrm{EBC}_{\mathrm{TR}} / \mathrm{EBC}$ at $950 \mathrm{~nm}$, derived with the above bestfit Aethalometer model parameters, and $\mathrm{EC}_{\mathrm{F}} / \mathrm{EC}$ are well correlated $(r=0.81$; see Fig. 3a) and the fitting residuals $\left(\triangle \mathrm{EBC}_{\mathrm{TR}} / \mathrm{EBC}=\mathrm{EBC}_{\mathrm{TR}} / \mathrm{EBC}-\mathrm{EC}_{\mathrm{F}} / \mathrm{EC}\right.$, Fig. 3b) are normally distributed with only a minor positive bias of $1.6 \%$. We estimate that the precision of the model $\left(\triangle \mathrm{EBC}_{\mathrm{TR}} / \mathrm{EBC}\right)$ is on average $9.3 \%$ in our case, using the standard deviation $(\sigma)$ of the Gaussian fit of $\triangle \mathrm{EBC}_{\mathrm{TR}} / \mathrm{EBC}$ in Fig. 3b. This indicates that the Aethalometer model reproduces reasonably well the ${ }^{14} \mathrm{C}$ results for all stations investigated in this study using our best estimate of a single $\alpha_{\mathrm{WB}}$ and $\alpha_{\mathrm{TR}}$ pair. Since this analysis includes data from urban stations as well as from spring and summer this shows that the Aethalometer model also works for other areas than for polluted Alpine valleys in winter. It should be noted that the determination of $\mathrm{EBC}_{\mathrm{TR}} / \mathrm{EBC}$ using the fitted $\alpha$ values cannot be more accurate than the uncertainty of $\mathrm{EC}_{\mathrm{F}} / \mathrm{EC}$. The estimated $\triangle \mathrm{EBC}_{\mathrm{TR}} / \mathrm{EBC}$ is affected by (1) random measurement uncertainties of $\mathrm{EC}_{\mathrm{F}} / \mathrm{EC}$ and $b_{\mathrm{abs}, 470}$ and $b_{\mathrm{abs}, 950}$ and (2) day-to-day and stationto-station variability in $\alpha_{\mathrm{WB}}$ and $\alpha_{\mathrm{TR}}$ values. Investigating the effect of a $\mathrm{MAC}_{\mathrm{TR}, 950} / \mathrm{MAC}_{\mathrm{WB}, 950}$ different from one $\left(\mathrm{MAC}_{\mathrm{TR}} / \mathrm{MAC}_{\mathrm{WB}}=0.7-1.3\right)$ it is evident that there is no large influence on $\alpha_{\mathrm{WB}}(1.66-1.71), \alpha_{\mathrm{TR}}(0.8-0.95)$, the mean bias (0.2-2.4\%), and $\triangle \mathrm{EBC}_{\mathrm{TR}} / \mathrm{EBC}(9.4-9.9 \%)$. This further justifies fixing the MAC ratio at unity when applying the Aethalometer model.

Without an alternative method for the source apportionment of $\mathrm{EC}$ or BC, the determination of $\alpha$ values and related uncertainties is unattainable. Therefore, we determined the distribution of $\alpha_{\mathrm{WB}}$ values for our data set and investigated whether there are other combinations of $\alpha_{\mathrm{TR}}$ and $\alpha_{\mathrm{WB}}$ that yield similarly acceptable agreement with ${ }^{14} \mathrm{C}$ data. For this 

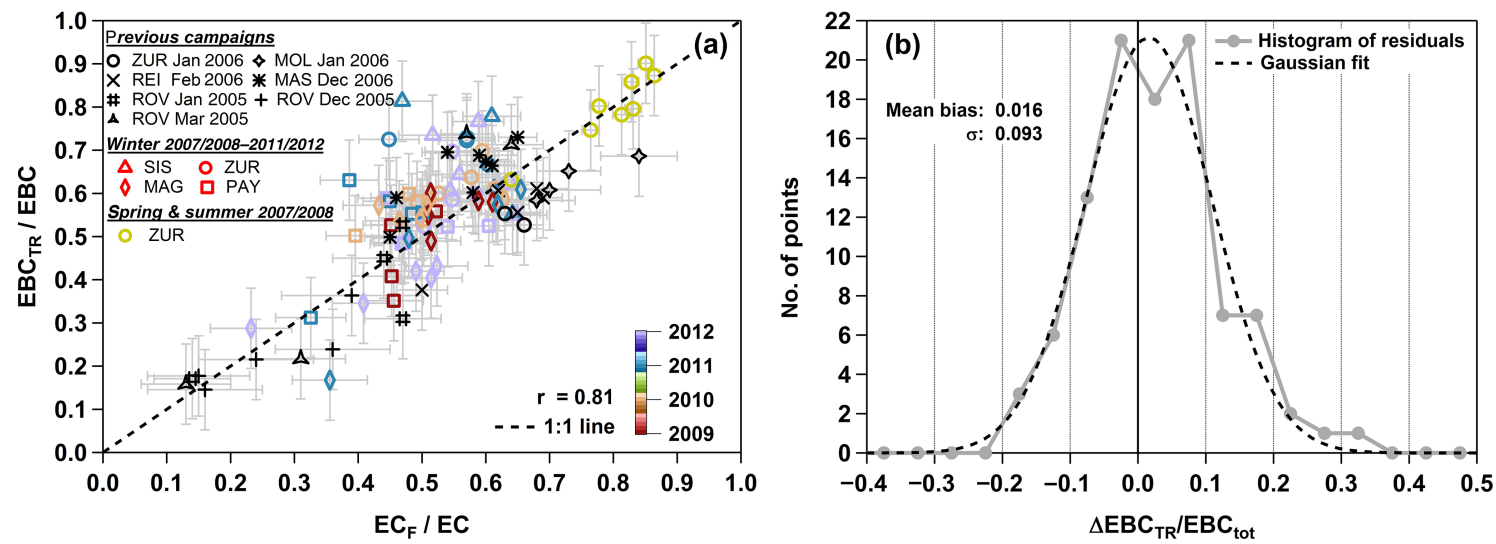

Figure 3. (a) Comparison between $\mathrm{EBC}_{\mathrm{TR}} / \mathrm{EBC}$ at $950 \mathrm{~nm}$ and $\mathrm{EC}_{\mathrm{F}} / \mathrm{EC}$ and (b) residuals of $\mathrm{EBC}_{\mathrm{TR}} / \mathrm{EBC}_{\mathrm{C}}$ compared to $\mathrm{EC}_{\mathrm{F}} / \mathrm{EC}$ $\left(\triangle \mathrm{EBC}_{\mathrm{TR}} / \mathrm{EBC}\right) . \mathrm{EBC}_{\mathrm{TR}} / \mathrm{EBC}$ was calculated using $b_{\mathrm{abs}, 470}, b_{\mathrm{abs}, 950}, \mathrm{MAC}_{\mathrm{TR}} / \mathrm{MAC}_{\mathrm{WB}}=1$, and the $\alpha$ values $(\alpha \mathrm{WB}=1.68$ and $\alpha_{\mathrm{TR}}=0.90$ ) obtained by fitting Eq. (13) against $\mathrm{EC}_{\mathrm{F}} / \mathrm{EC}$. The error bars for $\mathrm{EC}_{\mathrm{F}} / \mathrm{EC}$ represent the combined uncertainty of the ${ }^{14} \mathrm{C}$ measurement of EC, the extrapolation of $f_{\mathrm{M}, \mathrm{EC}}$ to $100 \% \mathrm{EC}$ yield, and the bomb peak correction (see Sect. 2.3). The error bars for $\mathrm{EBC}$ TR / $\mathrm{EBC}$ denote the standard deviation $(\sigma)$ of the Gaussian fit of $\triangle \mathrm{EBC}_{\mathrm{TR}} / \mathrm{EBC}$ as obtained in Fig. $3 \mathrm{~b}$.

purpose, Eq. (13) was solved for $\alpha_{\mathrm{WB}}$ :

$$
\begin{aligned}
& \alpha_{\mathrm{WB}}=\frac{-1}{\ln \left(\frac{\lambda_{1}}{\lambda_{2}}\right)} \\
& \cdot \ln \left(\frac{b_{\mathrm{abs}}\left(\lambda_{1}\right)}{b_{\mathrm{abs}}\left(\lambda_{2}\right)}+\frac{\frac{\operatorname{MAC}_{\mathrm{TR}}\left(\lambda_{2}\right)}{\operatorname{MAC}_{\mathrm{WB}}\left(\lambda_{2}\right)} \cdot\left(\left(\frac{\lambda_{1}}{\lambda_{2}}\right)^{-\alpha_{\mathrm{TR}}}-\frac{b_{\mathrm{abs}}\left(\lambda_{1}\right)}{b_{\mathrm{abs}}\left(\lambda_{2}\right)}\right)}{1-\frac{\mathrm{EC}}{\mathrm{EC}_{\mathrm{F}}}}\right) .
\end{aligned}
$$

This makes it possible to analytically calculate $\alpha_{\mathrm{WB}}$ for every single data point, if a fixed $\alpha_{\mathrm{TR}}$ is assumed and setting $\mathrm{MAC}_{\mathrm{TR}}$ to $\mathrm{MAC}_{\mathrm{WB}}$ to unity. $\alpha_{\mathrm{WB}}$ values were calculated for three different $\alpha_{\mathrm{TR}}$ values of $0.9,1.0$, and 1.1, which represent the range previously used in the literature. The resulting three $\alpha_{\text {WB }}$ distributions are displayed in Fig. 4. It is evident that an increase in $\alpha_{\mathrm{TR}}$ by 0.1 results in a concurrent decrease in $\alpha_{\mathrm{WB}}$ by 0.1 . This covariance between $\alpha_{\mathrm{TR}}$ and $\alpha_{\mathrm{WB}}$ implies that using combinations of $\alpha_{\mathrm{TR}}$ and $\alpha_{\mathrm{WB}}$ randomly altered (e.g., \pm 0.1 ) from the best $\alpha$ pair could result in high $\triangle \mathrm{EBC}_{\mathrm{TR}} / \mathrm{EBC}$. No clear station-to-station or seasonto-season differences in $\alpha_{\mathrm{WB}}$ were observed (see Table 2), though the number of samples from each station inspected here is limited for such analysis.

Investigating the different distributions in Fig. 4 only the range of $\alpha$ combinations resulting in the best agreement between the Aethalometer model and ${ }^{14} \mathrm{C}$ results of all individual data points can be obtained but it is not possible to determine other single $\alpha$ pairs representative for the entire data set. To investigate the bias in $\mathrm{EBC}_{\mathrm{TR}} / \mathrm{EBC}$ with respect to $\mathrm{EC}_{\mathrm{F}} / \mathrm{EC}\left(\triangle \mathrm{EBC}_{\mathrm{TR}} / \mathrm{EBC}\right)$ due to deviations of $\alpha_{\mathrm{TR}}$ and $\alpha_{\mathrm{WB}}\left(\Delta \alpha_{\mathrm{TR}}\right.$ and $\Delta \alpha_{\mathrm{WB}}$, respectively) from the best $\alpha$ pair, Eq. (13) was differentiated with respect to both parameters as a function of $\mathrm{EBC}_{\mathrm{TR}} / \mathrm{EBC}$. From Fig. S1 (in the Supplement) it is evident that $\triangle \mathrm{EBC}_{\mathrm{TR}} / \mathrm{EBC}$ is dependent on $\mathrm{EBC}_{\mathrm{TR}} / \mathrm{EBC}$ : for high and low values of the latter,
Table 2. Ranges and averages of $\alpha_{\mathrm{WB}}$ values resulting in a ratio of 1 between $\mathrm{EBC}_{\mathrm{TR}} / \mathrm{EBC}$ (at $950 \mathrm{~nm}$ ) and $\mathrm{EC}_{\mathrm{F}} / \mathrm{EC}$ for all stations calculated with $\alpha_{\mathrm{TR}}$ of $0.9, b_{\mathrm{abs}, 470}, b_{\mathrm{abs}, 950}$, and $\mathrm{MAC}_{\mathrm{TR}} / \mathrm{MAC}_{\mathrm{WB}}=1$.

\begin{tabular}{lll}
\hline Station & $\alpha_{\text {WB range }}$ & $\begin{array}{l}\alpha_{\text {WB mean }} \\
\pm \text { standard deviation }\end{array}$ \\
\hline SIS & $1.23-1.84$ & $1.55 \pm 0.21(n=9)$ \\
ZUR (winter) & $1.47-1.80$ & $1.67 \pm 0.11(n=14)$ \\
ZUR (summer) & $1.34-1.90$ & $1.60 \pm 0.14(n=8)$ \\
MAG & $1.53-1.85$ & $1.69 \pm 0.09(n=19)$ \\
PAY & $1.42-1.80$ & $1.63 \pm 0.10(n=19)$ \\
MOL & $1.85-2.17$ & $1.93 \pm 0.16(n=4)$ \\
ROV & $1.43-1.85$ & $1.68 \pm 0.11(n=13)$ \\
REI & $1.70-1.86$ & $1.81 \pm 0.06(n=5)$ \\
MAS & $1.46-1.65$ & $1.56 \pm 0.06(n=8)$ \\
\hline
\end{tabular}

$\Delta \mathrm{EBC}_{\mathrm{TR}} / \mathrm{EBC}$ is mainly driven by $\Delta \alpha_{\mathrm{TR}}$ and $\Delta \alpha_{\mathrm{WB}}$, respectively. A $\Delta \alpha_{\mathrm{WB}}$ of 0.1 yields a max. $\Delta \mathrm{EBC}_{\mathrm{TR}} / \mathrm{EBC}$ of $17 \%$ and a $\Delta \alpha_{\mathrm{WB}}$ of 0.2 already results in a max. $\Delta \mathrm{EBC}_{\mathrm{TR}} / \mathrm{EBC}$ of $33 \%$. On the other hand, a $\Delta \alpha_{\mathrm{TR}}$ of 0.2 results in only a max. $\triangle \mathrm{EBC}_{\mathrm{TR}} / \mathrm{EBC}$ of $19 \%$. Exploring $\Delta \mathrm{EBC}_{\mathrm{TR}} / \mathrm{EBC}$ for different $\alpha$ combinations $\left(\alpha_{\mathrm{TR}}=0.9-\right.$ 1.1 and $\alpha_{\mathrm{WB}}=1.4-2.2$ ) as a function of $\mathrm{EC}_{\mathrm{F}} / \mathrm{EC}$ (see Fig. 5) it is evident that other $\alpha$ pairs exist yielding low $\Delta \mathrm{EBC}_{\mathrm{TR}} / \mathrm{EBC}$ but, in contrast to the best $\alpha$ pair $\left(\alpha_{\mathrm{TR}}=0.9\right.$ and $\left.\alpha_{\mathrm{WB}}=1.68\right)$ not over the entire range of $\mathrm{EC}_{\mathrm{F}} / \mathrm{EC}$ found in this study. Especially for $\mathrm{EC}_{\mathrm{F}} / \mathrm{EC}<30 \%$ almost all $\alpha$ combinations, except the best pair, lead to a significant overor underestimation of $\mathrm{EBC}_{\mathrm{TR}} / \mathrm{EBC}$ compared to $\mathrm{EC}_{\mathrm{F}} / \mathrm{EC}$. Considering the $1 \sigma$ confidence interval of $\triangle \mathrm{EBC}_{\mathrm{TR}} / \mathrm{EBC}$ (minimum of $-0.6 \%$ and maximum of $14 \%$ ) as acceptable deviation from $\mathrm{EC}_{\mathrm{F}} / \mathrm{EC}$ also combinations of $\alpha_{\mathrm{TR}}=0.8$ (see Fig. S2) and 1.0 and $\alpha_{\mathrm{WB}}=1.8$ and 1.6, respectively, 


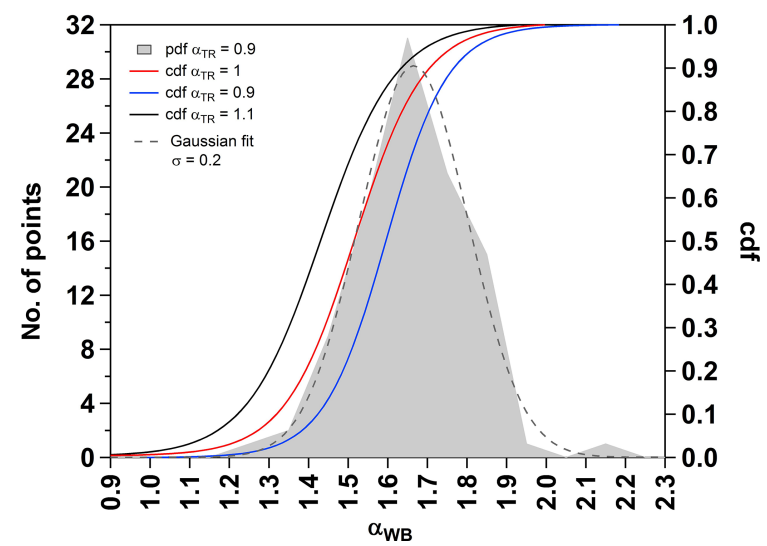

Figure 4. Histogram (pdf) and cumulative probability density function (cdf) of $\alpha_{\mathrm{WB}}$ if $\alpha_{\mathrm{WB}}$ is calculated for every data point, assuming a fixed $\alpha_{\mathrm{TR}}(0.9,1.0$, or 1.1$)$ and using $b_{\mathrm{abs}, 470}, b_{\mathrm{abs}, 950}$, and $\mathrm{MAC}_{\mathrm{TR}} / \mathrm{MAC}_{\mathrm{WB}}=1$.

are possible but only for a range of $\mathrm{EC}_{\mathrm{F}} / \mathrm{EC}$ between $\sim 40$ and $\sim 85 \%$. The $\alpha$ pair obtained by Sandradewi et al. (2008a) $\left(\alpha_{\mathrm{TR}}=1.1\right.$ and $\left.\alpha_{\mathrm{WB}}=1.86\right)$ who first used the Aethalometer model results in a constant positive bias of $\mathrm{EBC}_{\mathrm{TR}} / \mathrm{EBC}$ compared to $\mathrm{EC}_{\mathrm{F}} / \mathrm{EC}$ and does not even fall within the $3 \sigma$ confidence interval of $\triangle \mathrm{EBC}_{\mathrm{TR}} / \mathrm{EBC}$ (upper range $\sim 30 \%$ ). Furthermore, for $\alpha_{\mathrm{TR}}$ of 1.1 only a very narrow range of $\mathrm{EC}_{\mathrm{F}} / \mathrm{EC}$ (spanning maximum $20 \%$ ) exists resulting in $\triangle \mathrm{EBC}_{\mathrm{TR}} / \mathrm{EBC}$ within the $1 \sigma$ confidence interval. In addition, from Fig. 5 it is also evident that almost no $\alpha_{\text {WB }}$ previously used in the literature (1.8-2.2) would yield $\triangle \mathrm{EBC}_{\mathrm{TR}} / \mathrm{EBC}$ within the $1 \sigma$ confidence for our data set indicating that lower values of $\alpha_{\mathrm{WB}}$ should be used in the future in the Aethalometer model.

\subsubsection{Evaluation of the Aethalometer model against external data}

A further evaluation of the source apportionment results of the Aethalometer model was carried out by comparing $\mathrm{EBC}_{\mathrm{WB}}$ and $\mathrm{EBC}_{\mathrm{TR}}$ calculated with the best $\alpha_{\mathrm{TR}}$ and $\alpha_{\mathrm{WB}}$ pair (0.90 and 1.68, respectively) with other markers for traffic and biomass-burning emissions. Figure 6a presents the correlation of $\mathrm{NO}_{x}$, considered to be from traffic emissions, with $\mathrm{EBC}_{\mathrm{TR}}$, both averaged to $24 \mathrm{~h}$ from the NABEL stations PAY, MAG, and ZUR for the winter seasons 20092012, where Aethalometer and $\mathrm{NO}_{x}$ measurements were performed continuously for several years (see Sect. 2.5 and Table 1). Good correlations are found $(r=0.76-0.83)$ and all

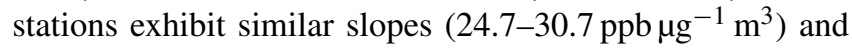
small axis intercepts (Fig. 6a). These slopes are comparable to London (18-28 $\mathrm{ppb} \mu \mathrm{g}^{-1} \mathrm{~m}^{3}$, Liu et al., 2014), Grenoble (33 $\mathrm{ppb} \mathrm{\mu g}^{-1} \mathrm{~m}^{3}$, Favez et al., 2010), and several other locations in Switzerland ( $32 \mathrm{ppb} \mathrm{\mu g}^{-1} \mathrm{~m}^{3}$, Zotter et al., 2014). Levoglucosan obtained on filter samples collected during the winter season and $\mathrm{EBC}_{\mathrm{WB}}$ were also found to be well corre-

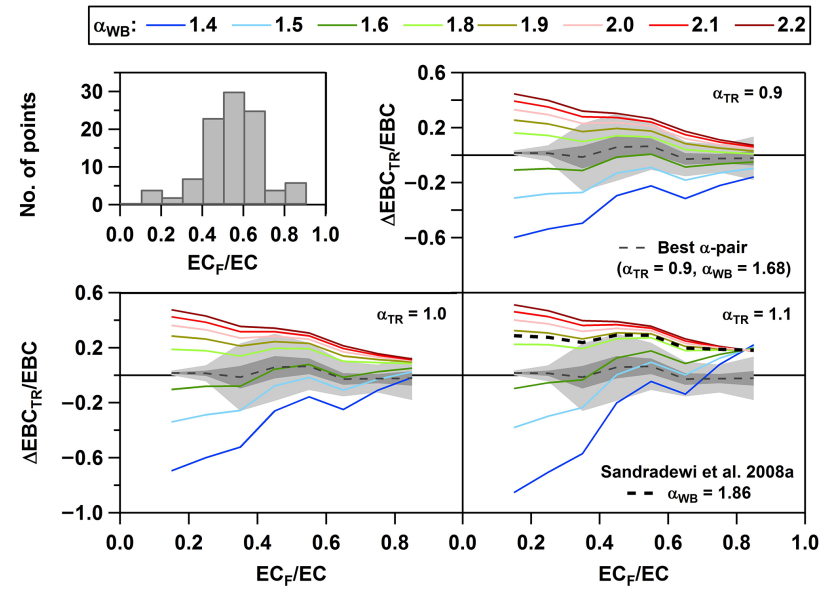

Figure 5. Residuals of $\mathrm{EBC}_{\mathrm{TR}} / \mathrm{EBC}$ compared to $\mathrm{EC}_{\mathrm{F}} / \mathrm{EC}$ $\left(\triangle \mathrm{EBC}_{\mathrm{TR}} / \mathrm{EBC}\right)$ as a function of $\mathrm{EC}_{\mathrm{F}} / \mathrm{EC}$ for different combinations of $\alpha_{\mathrm{TR}}$ and $\alpha_{\mathrm{WB}}$. Average $\Delta \mathrm{EBC}_{\mathrm{TR}} / \mathrm{EBC}$ values for $\mathrm{EC}_{\mathrm{F}} / \mathrm{EC}$ bins of 0.1 are calculated for $\alpha_{\mathrm{WB}}=1.4-2.2$ and $\alpha_{\mathrm{TR}}=0.9$ (upper right panel), $\alpha_{\mathrm{TR}}=1.0$ (lower left panel) and $\alpha_{\mathrm{TR}}=1.1$ (lower right panel). $\Delta \mathrm{EBC}_{\mathrm{TR}} / \mathrm{EBC}$ for $\alpha_{\mathrm{TR}}=0.8 \mathrm{can}$ be found in Fig. S2. The number of points per $\mathrm{EC}_{\mathrm{F}} / \mathrm{EC}$ bin is displayed in the upper left panel. The dashed grey line denotes the best $\alpha$ pair $\left(\alpha_{\mathrm{TR}}=0.9\right.$ and $\left.\alpha_{\mathrm{WB}}=1.68\right)$ as obtained in Sect. 3.2.1 and the dark and light grey shaded areas mark the $1 \sigma$ (standard deviation) and $3 \sigma$ of $\Delta \mathrm{EBC}_{\mathrm{TR}} / \mathrm{EBC}$ per $\mathrm{EC}_{\mathrm{F}} / \mathrm{EC}$ bin for this best $\alpha$ pair. The black dashed line in the lower right panel represents the $\alpha$ combination obtained by Sandradewi et al. (2008a) who first used the Aethalometer model.

lated ( $r=0.77$; see Fig. $6 \mathrm{~b})$ with also only a minor intercept. The slope obtained here (1.08) is also similar to other locations (1.0 for several other locations in Switzerland, Zotter et al., 2014; 0.76 for three sites in Austria, Caseiro et al., 2009; 1.12 in the Po-Valley, Gilardoni et al., 2009; Piazzalunga et al., 2011; and 1.68 in Grenoble, Favez et al., 2010).

\subsubsection{Comparison of $\alpha_{\mathrm{TR}}$ and $\alpha_{\mathrm{WB}}$ with literature values}

The $\alpha_{\mathrm{TR}}$ value obtained here (0.9) is lower than the values used in Sandradewi et al. (2008a) and many other studies (1.0-1.1, Favez et al., 2010; Crippa et al., 2013; Mohr et al., 2013). However, our findings are in agreement with those reported in Herich et al. (2011) showing that ambient $\alpha$ values in ZUR, MAG, and PAY in summer, when hardly any biomass-burning influence is expected, are around $\sim 0.9$. Herich et al. (2011) consequently used then this value as $\alpha_{\mathrm{TR}}$ in the Aethalometer model. Also Fuller et al. (2014) determined a value below 1 ( $\alpha_{\mathrm{TR}}$ of 0.96 ) for London.

The $\alpha_{\text {WB }}$ values obtained in this study are consistent with those reported from smog chamber experiments for fresh and aged biomass-burning emissions $(1.63 \pm 0.32$, Saleh et al., 2013), but are significantly lower than the values from Sandradewi et al. (2008a) often used by other source appor- 
tionment studies, i.e., 1.8-2.2 (Sandradewi et al., 2008a, b; Favez et al., 2010; Perron et al., 2010; Herich et al., 2011; Harrison et al., 2012, 2013; Crippa et al., 2013; Mohr et al., 2013). Note that Sandradewi et al. (2008a) determined their best pair of $\alpha$ values $\left(\alpha_{\mathrm{TR}}=1.1\right.$ and $\alpha_{\mathrm{WB}}=1.86 \mathrm{cal}-$ culated with $b_{\mathrm{abs}, 470}, b_{\mathrm{abs}, 950}$ and $\mathrm{MAC}_{\mathrm{TR}} / \mathrm{MAC} \mathrm{WB}_{\mathrm{WB}}=1$ ) by optimizing the ratio of the total fossil carbonaceous matter $\left(\mathrm{CM}_{\mathrm{F}} / \mathrm{CM}\right.$ instead of $\left.\mathrm{EC}_{\mathrm{TR}} / \mathrm{EC}\right)$ obtained from the ${ }^{14} \mathrm{C}$ measurements (see Sect. 3.4). Furthermore, Sandradewi et al. (2008a) did not account for the slight underestimation of biomass-burning EC as discussed in Zhang et al. (2012). Applying the approach presented in Sect. 3.2.2 to the data in Sandradewi et al. (2008a), using their value for $\alpha_{\mathrm{TR}}$ and $\mathrm{MAC}_{\mathrm{TR}} / \mathrm{MAC}_{\mathrm{WB}}$, yields $\alpha_{\mathrm{WB}}$ of 1.64 and 1.72 with and without extrapolation of $\mathrm{EC}_{\mathrm{F}} / \mathrm{EC}$ to $100 \% \mathrm{EC}$ yield, respectively, which is very similar to the values obtained in this study. Meanwhile, applying the pair of $\alpha$ values previously used from Sandradewi et al. (2008a) to determine $\mathrm{EBC}_{\mathrm{TR}} / \mathrm{EBC}$ from our data results in a mean positive bias $\left(\triangle \mathrm{EBC}_{\mathrm{TR}} / \mathrm{EBC}=18 \%\right)$, and therefore the use of this pair is not recommended in future studies.

Recently, Garg et al. (2016) investigated ambient $\alpha$ values in India for various biomass-combustion plumes including paddy- and wheat-residue burning, leaf litter, and garbage burning as well as traffic plumes. They found $\alpha$ values down to 1 for flaming biomass-combustion and $\alpha>1$ for older vehicles operating with poorly optimized engines and that $\alpha$ was mostly determined by the combustion efficiency. Therefore, if more than two tightly regulated BC sources, with well constrained combustion efficiencies are present, the $\alpha$ values might be different and additional evaluations of the choice of $\alpha_{\mathrm{WB}}$ and $\alpha_{\mathrm{TR}}$ in the Aethalometer model using a reference method are needed as well.

\subsubsection{Sensitivity due to different wavelength combinations}

As different pairs of N-UV and N-IR wavelengths (470 and 950, 470 and 880, and 370 and $880 \mathrm{~nm}$; see Perron et al., 2010; Herich et al., 2011 and Fuller et al., 2014) have been previously used in literature, we investigated the sensitivity of the Aethalometer model using different wavelength combinations by performing the same analysis as presented in Sect. 3.2.1 with different N-UV and N-IR pairs. In contrast to 470 and $950 \mathrm{~nm}$, no physically meaningful values for $\alpha_{\text {TR }}$ could be obtained for the other combinations by fitting Eq. (13) against $\mathrm{EC}_{\mathrm{F}} / \mathrm{EC}$ (see Table 3). Consequently, $\alpha_{\mathrm{TR}}$ was set to 0.9 to infer $\alpha_{\mathrm{WB}}$ for the combinations 470 and 880,370 and 950 , and 370 and $880 \mathrm{~nm}$. As shown in Table 3 different $\alpha_{\text {WB }}$ values for these wavelength pairs were obtained than for 470 and $950 \mathrm{~nm}$. Especially using $370 \mathrm{~nm}$ as the N-UV wavelength yielded a significantly higher $\alpha_{\mathrm{WB}}$ (2.09) than using $470 \mathrm{~nm}$ (1.68 and 1.75 for 470 and 950 and 470 and $880 \mathrm{~nm}$, respectively). It has been reported that $\alpha$ is wavelength dependent (e.g., Bond and Bergstrom, 2006), and might be more affected by fuel type, combustion, and atmospheric processes in the N-UV than in the visible part of the spectrum (Sandradewi et al., 2008c). Consequently, $\alpha_{\mathrm{WB}}$ can be different for different wavelength pairs. However, for all combinations, especially with $370 \mathrm{~nm}$ as N-UV wavelength, the mean residuals of $\mathrm{EBC}_{\mathrm{TR}} / \mathrm{EBC}$ compared to $\mathrm{EC}_{\mathrm{F}} / \mathrm{EC}$, were higher than using the 470 and $950 \mathrm{~nm}$ combination (see Table 3a). Next, $\mathrm{EBC}_{\mathrm{TR}} / \mathrm{EBC}$ was calculated with the best pair of $\alpha$ values $\left(\alpha_{\mathrm{WB}}=1.68\right.$ and $\alpha_{\mathrm{TR}}=0.90$ as obtained in Sect. 3.2.1) for the different wavelength combinations. It is evident that using $370 \mathrm{~nm}$ as N-UV wavelength $\mathrm{EBC}_{\mathrm{TR}} / \mathrm{EBC}$ exhibits an inferior agreement with $\mathrm{EC}_{\mathrm{F}} / \mathrm{EC}$ (see Table $3 \mathrm{~b}$ ). $\triangle \mathrm{EBC}_{\mathrm{TR}} / \mathrm{EBC}$ exhibits larger values, there is a significant number of negative points for $\mathrm{EBC}_{\mathrm{TR}} / \mathrm{EBC}$ and the correlations with $\mathrm{EC}_{\mathrm{F}} / \mathrm{EC}$ are weaker. On the other hand, similar $\triangle \mathrm{EBC}_{\mathrm{TR}} / \mathrm{EBC}$ and hardly any negative $\mathrm{EBC}_{\mathrm{TR}} / \mathrm{EBC}$ values are found for the wavelength combination 470 and $880 \mathrm{~nm}$.

Uncertainties in the source apportionment results using the Aethalometer model due to the use of different wavelength pairs are usually not considered and often the same $\alpha_{\text {WB }}$ and $\alpha_{\mathrm{TR}}$ values are used with different wavelength combinations. However, as shown here, the choice of the wavelengths, especially the one in the N-UV range, and $\alpha_{\mathrm{WB}}$ are not independent. Since (1) it was previously shown that adsorption of volatile organic compounds on the filter tape of the Aethalometer can occur which possibly influences the absorption measurement with the $370 \mathrm{~nm}$ channel (Vecchi et al., 2014), (2) light-absorbing SOA, other absorbing non$\mathrm{BC}$ combustion particles, and atmospheric processing affect lower wavelengths more than higher ones, and (3) our results indicate an inferior agreement of $\mathrm{EBC}_{\mathrm{TR}} / \mathrm{EBC}$ with $\mathrm{EC}_{\mathrm{F}} / \mathrm{EC}$ using $370 \mathrm{~nm}$ as N-UV wavelength, we therefore recommend using $470 \mathrm{~nm}$ as the N-UV wavelength in the Aethalometer model while the choice between 950 and $880 \mathrm{~nm}$ in the N-IR is less critical.

\subsubsection{High time resolution data}

Since Aethalometers measure with high time resolutions (e.g., model AE31 down to 2 min and the new model AE33 down to $1 \mathrm{~s}$ ) the investigation of the temporal behavior of $\mathrm{EBC}_{\mathrm{TR}}$ and $\mathrm{EBC}_{\mathrm{WB}}$ is possible (see, e.g., Herich et al., 2011). Figures 7 and S3 show the diurnal cycles for the stations MAG, PAY, and ZUR including continuous data from the entire years 2009 to 2012. It is evident that the Aethalometer can also be applied to high time resolution data and the expected temporal behavior of the sources can be resolved. The contribution of $\mathrm{EBC}_{\mathrm{WB}}$ is high in winter and during the night, with only small differences between weekends and weekdays. Furthermore, $\mathrm{EBC}_{\mathrm{TR}}$ exhibits a clear traffic peak in the morning during weekdays whereas during weekends this increase is not evident or only small.

We note that $\mathrm{EBC}_{\mathrm{WB}}$ also follows $\mathrm{EBC}_{\mathrm{TR}}$, with an evident increase during morning hours. This increase is statistically 
Table 3. Evaluation of the Aethalometer model using different wavelength pairs. (a) Calculation of the $\alpha$ values by fitting Eq. (13) $\left(\mathrm{MAC}_{\mathrm{TR}} / \mathrm{MAC}_{\mathrm{WB}}=1\right)$ against $\mathrm{EC}_{\mathrm{F}} / \mathrm{EC}$. (b) comparison between $\mathrm{EC}_{\mathrm{F}} / \mathrm{EC}$ and $\mathrm{EBC}_{\mathrm{TR}} / \mathrm{EBC}$ calculated with $\alpha_{\mathrm{WB}}=1.68$ and $\alpha_{\mathrm{WB}}=0.90$, representing the best $\alpha$ pair for all data, for different wavelength pairs. $\mu$ and $\sigma$ denote the center and the standard deviation of the Gaussian fit of the residuals of $\mathrm{EBC}_{\mathrm{TR}} / \mathrm{EBC}$ compared to $\mathrm{EC}_{\mathrm{F}} / \mathrm{EC}$, respectively.

\begin{tabular}{|c|c|c|c|c|}
\hline \multirow{2}{*}{$\begin{array}{l}\text { (a) } \\
\text { Wavelength pair }\end{array}$} & \multicolumn{4}{|c|}{ Calculation of best $\alpha$ values } \\
\hline & $\alpha_{\mathrm{WB}}$ & $\alpha_{\mathrm{TR}}$ & 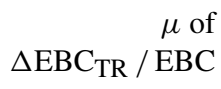 & 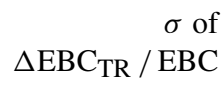 \\
\hline $470 \& 950 \mathrm{~nm}$ & 1.68 & 0.90 & $2 \%$ & $9 \%$ \\
\hline $470 \& 880 \mathrm{~nm}$ & 1.75 & $0.90^{*}$ & $7 \%$ & $11 \%$ \\
\hline $370 \& 950 \mathrm{~nm}$ & 2.09 & $0.90^{*}$ & $17 \%$ & $12 \%$ \\
\hline $370 \& 880 \mathrm{~nm}$ & 2.09 & $0.90^{*}$ & $18 \%$ & $13 \%$ \\
\hline (b) & \multicolumn{4}{|c|}{$\mathrm{EC}_{\mathrm{F}} / \mathrm{EC}$ vs. $\mathrm{EBC}_{\mathrm{TR}} / \mathrm{EBC}$ with $\alpha_{\mathrm{TR}}=0.90$ and $\alpha_{\mathrm{WB}}=1.68$} \\
\hline Wavelength pair & mean & negative & $r$ & \\
\hline & $\Delta \mathrm{EBC}_{\mathrm{TR}} / \mathrm{EBC}$ & $\mathrm{EBC}_{\mathrm{TR}} / \mathrm{EBC}$ points & (with $\mathrm{EC}_{\mathrm{F}} / \mathrm{EC}$ ) & \\
\hline $470 \& 950 \mathrm{~nm}$ & $2 \%$ & $0 \%$ & 0.80 & \\
\hline $470 \& 880 \mathrm{~nm}$ & $3 \%$ & $3 \%$ & 0.65 & \\
\hline $370 \& 950 \mathrm{~nm}$ & $-12 \%$ & $16 \%$ & 0.63 & \\
\hline $370 \& 880 \mathrm{~nm}$ & $-15 \%$ & $19 \%$ & 0.58 & \\
\hline
\end{tabular}

* No physically meaningful value for $\alpha_{\mathrm{TR}}$ could be obtained by the fitting of Eq. (13) against $\mathrm{EC}_{\mathrm{F}} / \mathrm{EC}$ and therefore $\alpha_{\mathrm{TR}}$ was set to 0.9 representing the best value for the wavelength pair 470 and $950 \mathrm{~nm}$.

larger than our uncertainties (14-18 in winter and 30-75\% in summer). This indicates that there is some false attribution of $\mathrm{EBC}_{\mathrm{TR}}$ and $\mathrm{EBC}_{\mathrm{WB}}$ most probably due to the constant a priori assumed pair of $\alpha_{\mathrm{WB}}$ and $\alpha_{\mathrm{TR}}$. By applying different $\alpha$ combinations for ZUR $\left(\alpha_{\mathrm{WB}}=1.68\right.$ and $\alpha_{\mathrm{TR}}=0.90$, $\alpha_{\mathrm{WB}}=1.68$ and $\alpha_{\mathrm{TR}}=1.1, \alpha_{\mathrm{WB}}=1.9$ and $\alpha_{\mathrm{TR}}=0.90$ as well as $\alpha_{\mathrm{WB}}=1.9$ and $\left.\alpha_{\mathrm{TR}}=1.1\right)$ this false attribution between $\mathrm{EBC}_{\mathrm{TR}}$ and $\mathrm{EBC}_{\mathrm{WB}}$ during the morning peak disappears (see Fig. S4), indicating that a higher $\alpha_{\mathrm{TR}}$ would be more representative of fresh traffic emissions in the case of ZUR. Since the evaluation of $\alpha$ combinations presented in this paper is based on longer sampling times and mostly winter data (16 to $40 \mathrm{~h}$; see Table 1 ), caution should be taken when applying the Aethalometer model with the best $\alpha$ pair found here to high time resolution data, especially for low EBC concentrations and rush hours. Similar studies with higher time resolutions, and for EBC concentrations, like in summer, are necessary for a further evaluation of the Aethalometer model.

\subsection{Traffic and wood-burning contributions to EC and EBC}

The relative traffic contribution as apportioned by the Aethalometer model $\left(\mathrm{EBC}_{\mathrm{TR}} / \mathrm{EBC}\right)$ and the ${ }^{14} \mathrm{C}$ analysis $\left(\mathrm{EC}_{\mathrm{F}} / \mathrm{EC}\right.$ ) of EBC and $\mathrm{EC}$, respectively, is often $>50 \%$ (see Fig. 3a). However, since hardly any $\mathrm{EC}_{\mathrm{F}} / \mathrm{EC}$ values, except results from the summer season, are above $70 \%$ and the average of $\mathrm{EC}_{\mathrm{F}} / \mathrm{EC}$ over all winter samples is $52 \pm 17 \%$, it is evident that also wood-burning emissions account for a large fraction of EC (and thus EBC) during winter in Switzer- land. The traffic contributions for winter samples range from 7 to 82 and 14 to $84 \%$ for EBC and EC, respectively. The lowest values $\left(31 \pm 23\right.$ and $36 \pm 17 \%$ for $\mathrm{EBC}_{\mathrm{TR}} / \mathrm{EBC}$ and $\mathrm{EC}_{\mathrm{F}} / \mathrm{EC}$, respectively) were found at ROV which is most likely due to a combination of topography (ROV is located in an Alpine valley), local meteorology (often persistent inversions with low mixing heights) and emissions (high local wood-burning influence; Alfarra et al., 2007; Szidat et al., 2007; Lanz et al., 2008; Sandradewi et al., 2008a, c; Herich et al., 2014; Zotter et al., 2014). The samples from ZUR, the largest city of Switzerland, collected during spring and summer clearly show the highest fossil contributions with an average of $81 \pm 10$ and $80 \pm 7 \%$ and the highest value of 92 and $85 \%$ for $\mathrm{EBC}_{\mathrm{TR}} / \mathrm{EBC}$ and $\mathrm{EC}_{\mathrm{F}} / \mathrm{EC}$, respectively.

Investigating the diurnal cycles of $\mathrm{EBC}_{\mathrm{WB}}$, it is evident that the concentrations are high in winter, especially in MAG and during night-time, with no or only small differences between weekends and weekdays. Concentrations in summer are lower but non-negligible, with significantly (paired $t$ test, significance level of 0.05 ) higher concentrations in Zurich compared to the other locations, especially during night-times on weekends. This suggests an additional source of brown carbon in ZUR, likely related to primary emissions enhanced with urban activities, during weekends, and with higher emissions in an increasingly shallower nighttime boundary layer. Contribution of secondary processes to the brown carbon background concentrations observed at all sites cannot be excluded. $\mathrm{EBC}_{\mathrm{TR}}$ concentrations for weekdays are significantly higher in winter compared to summer and also for weekends in MAG ( $t$ test, significance level of 

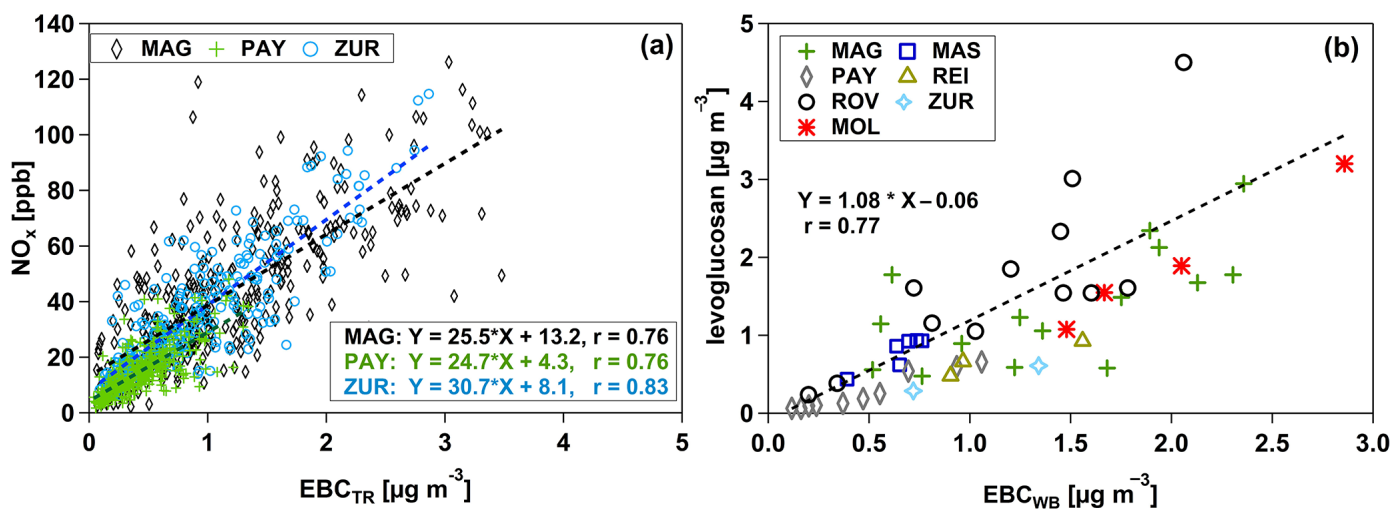

Figure 6. Comparison of the Aethalometer model outputs calculated with the $\alpha$ values $\left(\alpha_{\mathrm{WB}}=1.68\right.$ and $\left.\alpha_{\mathrm{TR}}=0.90\right)$ obtained by fitting Eq. (13) against $\mathrm{EC}_{\mathrm{F}} / \mathrm{EC}$ with the additional traffic $\left(\mathrm{NO}_{x}\right)$ and wood-burning (levoglucosan) markers: (a) the correlation between $\mathrm{EBC}_{\mathrm{TR}}$ at $950 \mathrm{~nm}$ and $\mathrm{NO}_{x}$ averaged to $24 \mathrm{~h}$; and (b) the scatterplot between the $\mathrm{EBC}_{\mathrm{WB}}$ at $950 \mathrm{~nm}$ and levoglucosan. Details of the origin of the data are given in Table 1.
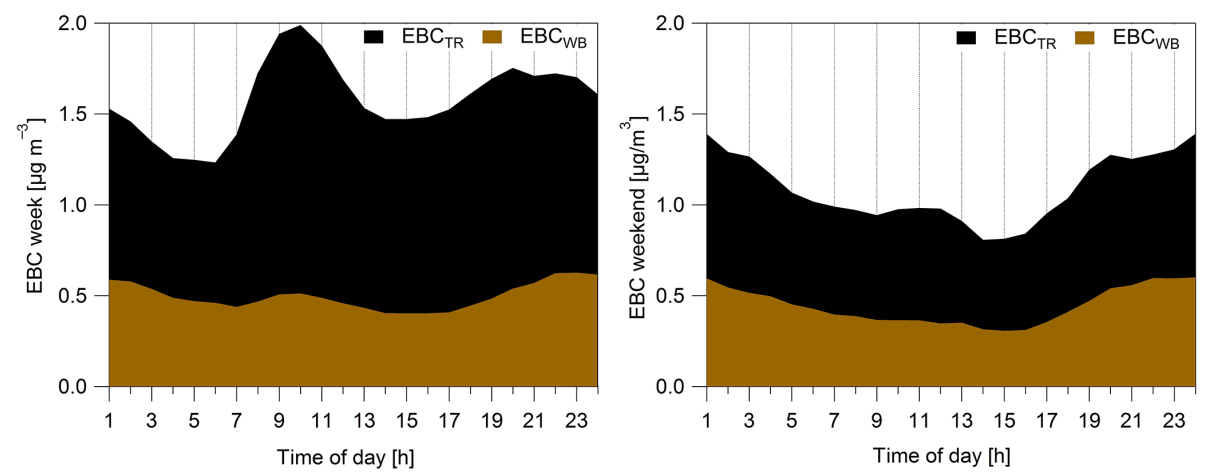

Figure 7. Diurnal cycle at ZUR including $1 \mathrm{~h}$ winter data from 2009 to 2012 . $\mathrm{EBC}_{\mathrm{WB}}$ and $\mathrm{EBC}_{\mathrm{TR}}$ were calculated using the best $\alpha$ pair $\left(\alpha_{\mathrm{TR}}=0.9\right.$ and $\left.\alpha_{\mathrm{WB}}=1.68\right)$ as obtained in Sect. 3.2.1. The split uncertainty between $\mathrm{EBC}_{\mathrm{WB}}$ and $\mathrm{EBC}_{\mathrm{TR}}\left(\Delta \mathrm{EBC}_{\mathrm{TR}} / \mathrm{EBC}\right)$ is max. $0.04 \mu \mathrm{g} \mathrm{m}^{-3}$.

0.05). In contrast, in ZUR and PAY, average $\mathrm{EBC}_{\mathrm{TR}}$ weekend concentrations are very similar. Weekday $\mathrm{EBC}_{\mathrm{TR}}$ concentrations exhibit a clear morning peak for all stations and seasons, which is less evident on weekends. The lowest concentrations are found in PAY and the highest in MAG in winter. In summer, $\mathrm{EBC}_{\mathrm{TR}}$ is highest in ZUR days.

\subsection{Traffic and wood-burning contributions to PM}

It has been attempted to also apportion the total carbonaceous material $(\mathrm{CM})$ to wood-burning $\left(\mathrm{CM}_{\mathrm{WB}}\right)$ and traffic $\left(\mathrm{CM}_{\mathrm{TR}}\right.$; e.g., Sandradewi et al., 2008a) according to the following equations:

$$
\begin{aligned}
\mathrm{CM} & =\mathrm{OM}+\mathrm{BC}, \quad \text { OM. .organic matter } \\
\mathrm{CM} & =\mathrm{CM}_{\mathrm{TR}}+\mathrm{CM}_{\mathrm{WB}}+\mathrm{CM}_{\mathrm{other}} \\
& =c_{1} \times b_{\mathrm{abs}, \mathrm{TR}, 950}+c_{2} \times b_{\mathrm{abs}, \mathrm{WB}, 470}+c_{3}
\end{aligned}
$$

If CM is determined independently, $c_{1}$ and $c_{2}$ can be obtained by solving Eq. (17), relating the light absorption to the particulate mass of both sources. The intercept $c_{3}$ represents a con- stant background concentration of non-absorbing carbonaceous material $\left(\mathrm{CM}_{\text {other }}\right)$. While Sandradewi et al. (2008a) did not require $\mathrm{CM}_{\text {other }}$ to achieve mass closure, Favez et al. (2010), Harrison et al. (2013), and Herich et al. (2011) found significant contributions of $\mathrm{CM}_{\text {other }}$.

In practice, site-specific $c_{1}, c_{2}$, and $c_{3}$ values may be either fitted using Eq. (17) or less commonly fixed based on the knowledge of the OM-to-EC ratios in the primary emissions of interest (most frequently, only $c_{1}$ is fixed, e.g., Favez et al., 2010). The two approaches do not necessarily lead to the same result as they are not based on the same conceptual definitions of the organic aerosol fractions. When derived from the multiple linear regression fitting of Eq. (17), $\mathrm{CM}_{\mathrm{TR}}$ and $\mathrm{CM}_{\mathrm{WB}}$ would represent the fractions that corre-

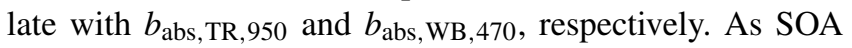
production is often very rapid (Huang et al., 2014), $\mathrm{CM}_{\mathrm{TR}}$ and $\mathrm{CM}_{\mathrm{WB}}$ are also expected to partially contain not only primary OA, but also SOA produced through the aging of traffic and wood-burning emissions, respectively. Note that correlation is not causation and some of these correlations are a 
direct consequence of meteorology and planetary boundary layer mixing. This may significantly complicate data interpretation. Using this methodology, Herich et al. (2014) could not precisely quantify the contributions of the different $\mathrm{CM}$ sources. They found a standard error of $\pm 30 \%$ for $c_{1}, c_{2}$, and $c_{3}$ and a high sensitivity of $c_{1}$ and $c_{2}$ on the chosen $\alpha$ values for wood burning and traffic emissions. This is one of the few cases where errors related to CM apportionment using Aethalometer data are explicitly estimated. Usually only the sensitivity of $c_{1}, c_{2}$, and $c_{3}$ on the chosen $\alpha$ values is reported. However, the most profound flaw in the application of Eq. (17) using a multiple linear regression is the assumption that $c_{3}$, which is non-absorbing SOA mass mostly, is constant over time. Consequently, assessing how this mass is apportioned among the different sources and model residuals remains elusive and more faithful representation of the complex atmospheric processes would necessitate the use of a robust tracer for SOA. Accordingly, we do not recommend the use of this model in its current state to apportion the CM mass, especially when the SOA fraction is dominant and highly variable.

A more conservative and controlled approach is to fix in the model the values of $c_{1}$ and $c_{2}$, based on emission data, and attribute the time-dependent remainder $\left(c_{3}\right)$ to SOA. Under these conditions, $\mathrm{CM}_{\mathrm{TR}}$ and $\mathrm{CM}_{\mathrm{WB}}$ relate to the primary fraction and the model may better capture the time variability of SOA. Indeed, this approach would entail the precise knowledge of $c_{1}$ and $c_{2}$. OM-to-EC ratios in traffic emissions are heavily dependent on the type of fuel used, with lower values reported for diesel exhausts. Accordingly, for a European fleet dominated by diesel cars, El Haddad et al. (2013) report OM-to-EC ratios ranging between $0.25-0.45$, whereas in the US, ratios between 0.9 and 1.4 were found (Zhang et al., 2005; Sun et al., 2012; Stroud et al., 2012). As biomass burning is a poorly controlled combustion process, typical OM-to-EC ratios determined at emissions are highly scattered, ranging between 3 and 63 (Schauer et al., 2001; Fine et al., 2001, 2002, 2004a, b; Schmidl et al., 2008). Nevertheless, more useful information may be obtained from examining ambient measurements, where, depending on the approach used to quantify wood smoke, OM-to-EC ratios may range between 3 and 18 (Favez et al., 2010; Herich et al., 2014; Zotter et al., 2014). While these ratios must be selected with extreme caution and the sensitivity of the source apportionment results to this selection must be systematically assessed, additional on-site data (e.g., levoglucosan, ${ }^{14} \mathrm{C} .$. ) may always aid constraining their values.

\section{Conclusions}

In this study, we show a comparison of the source apportionment of equivalent black carbon (EBC) using the Aethalometer model with radiocarbon $\left({ }^{14} \mathrm{C}\right)$ measurements of elemental carbon (EC). This enables a validation of the choice of the absorption Ångström exponents for wood-burning $\left(\alpha_{\mathrm{WB}}\right)$ and traffic $\left(\alpha_{\mathrm{TR}}\right)$ emissions which have to be assumed a priori in the Aethalometer model. Data from several campaigns across Switzerland with parallel Aethalometer and ${ }^{14} \mathrm{C}$ measurements of the EC fraction from eight different stations with different characteristics allow the investigation of the applicability and performance of the Aethalometer model for different locations and conditions.

To obtain the best $\alpha$ pair in the Aethalometer model, outputs (using the 470 and $950 \mathrm{~nm}$ channels) were fitted against the fossil fraction of $\mathrm{EC}\left(\mathrm{EC}_{\mathrm{F}} / \mathrm{EC}\right)$ derived from ${ }^{14} \mathrm{C}$ measurements resulting in $\alpha_{\mathrm{TR}}=0.9$ and $\alpha_{\mathrm{WB}}=1.68$. The source apportionment results from both methods, Aethalometer and ${ }^{14} \mathrm{C}$, are well correlated $(r=0.81)$ and the fitting residuals exhibit only a minor positive bias of $1.6 \%$ and an average precision of $9.3 \%$, indicating that the Aethalometer model reproduces reasonably well the ${ }^{14} \mathrm{C}$ results for all stations investigated in this study using our best estimate of a single $\alpha_{\mathrm{WB}}$ and $\alpha_{\mathrm{TR}}$ pair. We show that the Aethalometer model also works for other areas than for polluted Alpine valleys in winter, since this analysis includes data from urban stations as well as days from spring and summer.

The residuals of the Aethalometer model outputs $\left(\triangle \mathrm{EBC}_{\mathrm{TR}} / \mathrm{EBC}\right)$ calculated with other $\alpha$ pairs depend on $\mathrm{EC}_{\mathrm{F}} / \mathrm{EC}$ and a good agreement (within the $1 \sigma$ confidence interval of $\triangle \mathrm{EBC}_{\mathrm{TR}} / \mathrm{EBC}$ ) cannot be obtained over the entire $\mathrm{EC}_{\mathrm{F}} / \mathrm{EC}$ range using other $\alpha$ pairs. However, combinations of $\alpha_{\mathrm{TR}}=0.8$ and 1.0 and $\alpha_{\mathrm{WB}}=1.8$ and 1.6, respectively, are also possible but only for a range of $\mathrm{EC}_{\mathrm{F}} / \mathrm{EC}$ between $\sim 40$ and $\sim 85 \%$. The $\alpha_{\text {WB }}$ values previously used in Aethalometer models $(\sim 2)$ and any combination with $\alpha_{\mathrm{TR}}=1.1$ yield significant positive biases in the fitting residuals. Therefore we recommend to use the best $\alpha$ combination as obtained here $\left(\alpha_{\mathrm{TR}}=0.9\right.$ and $\alpha_{\mathrm{WB}}=1.68$ for the wavelength pair 470 and $950 \mathrm{~nm}$ ) in future studies. We also tested the sensitivity of the Aethalometer model due to different pairs of near-UV (N-UV) and near-IR (N-IR) wavelengths (470 and 950, 470 and 880, and 370 and $880 \mathrm{~nm}$ ). Any combination with $370 \mathrm{~nm}$ as N-UV wavelength resulted in larger residuals, a significant number of negative points, and weaker correlations with $\mathrm{EC}_{\mathrm{F}} / \mathrm{EC}$ and, therefore, we recommend to use $470 \mathrm{~nm}$ as N-UV wavelength in the Aethalometer model. Using 950 or $880 \mathrm{~nm}$ as N-IR wavelengths showed similar results, though the former wavelength performed slightly better in this study.

Having an independent measurement for the relative contributions of traffic and wood-burning to total EC from the ${ }^{14} \mathrm{C}$ and Aethalometer measurements, also made it possible to assess the dependence of the mass absorption cross section (MAC) of EBC on its source. The results indicate no significant difference in MAC at $880 \mathrm{~nm}$ (with a value of $11.8 \mathrm{~m}^{2} \mathrm{~g}^{-1}$ ) between EBC originating from traffic or woodburning emissions. 
Applying the Aethalometer model to apportion total carbonaceous material $(\mathrm{CM})$ it is evident that there are significant uncertainties and model errors (mainly due to assuming constant fitting parameters relating the absorption of traffic, wood-burning and the residuals (comprising non-lightabsorbing CM, mostly secondary organic aerosol) to the separately determined $\mathrm{CM}$ ). Therefore, in our opinion such a $\mathrm{CM}$ apportionment should only be interpreted qualitatively.

The results obtained in this study demonstrate that the evaluation of the choice of $\alpha_{\mathrm{WB}}$ and $\alpha_{\mathrm{TR}}$ using a reference method is highly valuable and should be performed when applying the Aethalometer model, if possible. In the absence of such reference measurements, however, assuming a single set of $\alpha_{\mathrm{TR}}$ and $\alpha_{\mathrm{WB}}$ yields acceptable results (i.e., average precision of $9.3 \%$ of $\mathrm{EBC}_{\mathrm{TR}} / \mathrm{EBC}$ compared to $\mathrm{EC}_{\mathrm{F}} / \mathrm{EC}$ in our case) and provides the best estimate of the fossil and non-fossil contributions to EBC as apportioned by the Aethalometer model. Nevertheless, these results were obtained for locations impacted by BC mainly from traffic consisting of a modern car fleet and wood combustion for residential heating in winter with well-constrained combustion efficiencies. Furthermore, mainly winter conditions with only a few summer samples were available. Therefore, additional studies about the performance of the Aethalometer model with respect to seasonality and for sites with different combustion conditions and efficiencies, sources, and fuels used and their temporal evolution are needed to reduce the uncertainties of their choice in the Aethalometer model.

Data availability. The data are available from the authors upon request.

\section{The Supplement related to this article is available online at doi:10.5194/acp-17-4229-2017-supplement.}

Competing interests. Griša Močnik is employed by Aerosol d.o.o., which develops and manufactures the Aethalometer.

Acknowledgements. This work was funded by the Swiss Federal Office for the Environment (BAFU), inNet Monitoring AG, OSTLUFT, the country of Liechtenstein and the Swiss cantons Basel-Stadt, Basel-Landschaft, Graubünden, St. Gallen, Solothurn, Valais and Ticino. Martin Gysel was supported by the ERC under grant ERC-CoG 615922-BLACARAT.

Edited by: W. Maenhaut

Reviewed by: five anonymous referees

\section{References}

Alfarra, M. R., Prevot, A. S. H., Szidat, S., Sandradewi, J., Weimer, S., Lanz, V. A., Schreiber, D., Mohr, M., and Baltensperger, U.: Identification of the mass spectral signature of organic aerosols from wood burning emissions, Environ. Sci. Technol., 41, 57705777, doi:10.1021/es062289b, 2007.

Barmpadimos, I., Hueglin, C., Keller, J., Henne, S., and Prévôt, A. S. H.: Influence of meteorology on $\mathrm{PM}_{10}$ trends and variability in Switzerland from 1991 to 2008, Atmos. Chem. Phys., 11, 18131835, doi:10.5194/acp-11-1813-2011, 2011.

Barmpadimos, I., Keller, J., Oderbolz, D., Hueglin, C., and Prévôt, A. S. H.: One decade of parallel fine $\left(\mathrm{PM}_{2.5}\right)$ and coarse $\left(\mathrm{PM}_{10}-\mathrm{PM}_{2.5}\right)$ particulate matter measurements in Europe: trends and variability, Atmos. Chem. Phys., 12, 3189-3203, doi:10.5194/acp-12-3189-2012, 2012.

Bernardoni, V., Calzolai, G., Chiari, M., Fedi, M., Lucarelli, F., Nava, S., Piazzalunga, A., Riccobono, F., Taccetti, F., Valli, G., and Vecchi, R.: Radiocarbon analysis on organic and elemental carbon in aerosol samples and source apportionment at an urban site in Northern Italy, J. Aerosol Sci., 56, 88-99, doi:10.1016/j.jaerosci.2012.06.001, 2013.

Bond, T. C. and Bergstrom, R. W.: Light absorption by carbonaceous particles: An investigative review, Aerosol Sci. Tech., 40, 27-67, doi:10.1080/02786820500421521, 2006.

Bond, T. C., Anderson, T. L., and Campbell, D.: Calibration and intercomparison of filter-based measurements of visible light absorption by aerosols, Aerosol Sci. Tech., 30, 582-600, doi:10.1080/027868299304435, 1999.

Bond, T. C., Doherty, S. J., Fahey, D. W., Forster, P. M., Berntsen, T., DeAngelo, B. J., Flanner, M. G., Ghan, S., Kärcher, B., Koch, D., Kinne, S., Kondo, Y., Quinn, P. K., Sarofim, M. C., Schultz, M. G., Schulz, M., Venkataraman, C., Zhang, H., Zhang, S., Bellouin, N., Guttikunda, S. K., Hopke, P. K., Jacobson, M. Z., Kaiser, J. W., Klimont, Z., Lohmann, U., Schwarz, J. P., Shindell, D., Storelvmo, T., Warren, S. G., and Zender, C. S.: Bounding the role of black carbon in the climate system: A scientific assessment, J. Geophys. Res.-Atmos., 118, 5380-5552, doi:10.1002/jgrd.50171, 2013.

Caseiro, A., Bauer, H., Schmidl, C., Pio, C. A., and Puxbaum, H.: Wood burning impact on PM10 in three Austrian regions, Atmos. Environ., 43, 2186-2195, doi:10.1016/j.atmosenv.2009.01.012, 2009.

Cavalli, F., Viana, M., Yttri, K. E., Genberg, J., and Putaud, J.-P.: Toward a standardised thermal-optical protocol for measuring atmospheric organic and elemental carbon: the EUSAAR protocol, Atmos. Meas. Tech., 3, 79-89, doi:10.5194/amt-3-79-2010, 2010.

Cercl'Air: Schweizerische Gesellschaft der Lufthygiene-Fachleute: available at: http://www.cerclair.ch/ (last access: 3 July 2016), 2012.

Collaud Coen, M., Weingartner, E., Schaub, D., Hueglin, C., Corrigan, C., Henning, S., Schwikowski, M., and Baltensperger, U.: Saharan dust events at the Jungfraujoch: detection by wavelength dependence of the single scattering albedo and first climatology analysis, Atmos. Chem. Phys., 4, 2465-2480, doi:10.5194/acp4-2465-2004, 2004.

Collaud Coen, M., Weingartner, E., Apituley, A., Ceburnis, D., Fierz-Schmidhauser, R., Flentje, H., Henzing, J. S., Jennings, S. G., Moerman, M., Petzold, A., Schmid, O., and Baltensperger, 
U.: Minimizing light absorption measurement artifacts of the Aethalometer: evaluation of five correction algorithms, Atmos. Meas. Tech., 3, 457-474, doi:10.5194/amt-3-457-2010, 2010.

Crilley, L. R., Bloss, W. J., Yin, J., Beddows, D. C. S., Harrison, R. M., Allan, J. D., Young, D. E., Flynn, M., Williams, P., Zotter, P., Prevot, A. S. H., Heal, M. R., Barlow, J. F., Halios, C. H., Lee, J. D., Szidat, S., and Mohr, C.: Sources and contributions of wood smoke during winter in London: assessing local and regional influences, Atmos. Chem. Phys., 15, 3149-3171, doi:10.5194/acp15-3149-2015, 2015.

Crippa, M., DeCarlo, P. F., Slowik, J. G., Mohr, C., Heringa, M. F., Chirico, R., Poulain, L., Freutel, F., Sciare, J., Cozic, J., Di Marco, C. F., Elsasser, M., Nicolas, J. B., Marchand, N., Abidi, E., Wiedensohler, A., Drewnick, F., Schneider, J., Borrmann, S., Nemitz, E., Zimmermann, R., Jaffrezo, J.-L., Prévôt, A. S. H., and Baltensperger, U.: Wintertime aerosol chemical composition and source apportionment of the organic fraction in the metropolitan area of Paris, Atmos. Chem. Phys., 13, 961-981, doi:10.5194/acp-13-961-2013, 2013.

Currie, L. A.: Evolution and multidisciplinary frontiers of ${ }^{14} \mathrm{C}$ aerosol science, Radiocarbon, doi:10.2458/azu_js_rc.v.3857, 2000.

Drinovec, L., Mocnik, G., Zotter, P., Prévôt, A. S. H., Ruckstuhl, C., Coz, E., Rupakheti, M., Sciare, J., Müller, T., Wiedensohler, A., and Hansen, A. D. A.: The "dual-spot" Aethalometer: an improved measurement of aerosol black carbon with realtime loading compensation, Atmos. Meas. Tech., 8, 1965-1979, doi:10.5194/amt-8-1965-2015, 2015.

Dusek, U., Monaco, M., Prokopiou, M., Gongriep, F., Hitzenberger, R., Meijer, H. A. J., and Röckmann, T.: Evaluation of a twostep thermal method for separating organic and elemental carbon for radiocarbon analysis, Atmos. Meas. Tech., 7, 1943-1955, doi:10.5194/amt-7-1943-2014, 2014.

El Haddad, I., Marchand, N., Wortham, H., Piot, C., Besombes, J.L., Cozic, J., Chauvel, C., Armengaud, A., Robin, D., and Jaffrezo, J.-L.: Primary sources of $\mathrm{PM}_{2.5}$ organic aerosol in an industrial Mediterranean city, Marseille, Atmos. Chem. Phys., 11, 2039-2058, doi:10.5194/acp-11-2039-2011, 2011.

El Haddad, I., D’Anna, B., Temime-Roussel, B., Nicolas, M., Boreave, A., Favez, O., Voisin, D., Sciare, J., George, C., Jaffrezo, J.-L., Wortham, H., and Marchand, N.: Towards a better understanding of the origins, chemical composition and aging of oxygenated organic aerosols: case study of a Mediterranean industrialized environment, Marseille, Atmos. Chem. Phys., 13, 78757894, doi:10.5194/acp-13-7875-2013, 2013.

EMPA: Technischer Bericht zum Nationalen Beobachtungsnetz für Luftfremdstoffe (NABEL), Dübendorf, Switzerland, 2013.

Eurostat: Energy Statistics, Main Tables: http://ec.europa.eu/ eurostat/web/energy/data/main-tables, last access: 11 January 2017.

Favez, O., El Haddad, I., Piot, C., Boréave, A., Abidi, E., Marchand, N., Jaffrezo, J.-L., Besombes, J.-L., Personnaz, M.-B., Sciare, J., Wortham, H., George, C., and D'Anna, B.: Inter-comparison of source apportionment models for the estimation of wood burning aerosols during wintertime in an Alpine city (Grenoble, France), Atmos. Chem. Phys., 10, 5295-5314, doi:10.5194/acp-10-52952010, 2010.

Fine, P. M., Cass, G. R., and Simoneit, B. R. T.: Chemical characterization of fine particle emissions from fireplace combustion of woods grown in the northeastern United States, Environ. Sci. Technol., 35, 2665-2675, doi:10.1021/es001466k, 2001.

Fine, P. M., Cass, G. R., and Simoneit, B. R. T.: Chemical characterization of fine particle emissions from the fireplace combustion of woods grown in the southern United States, Environ. Sci. Technol., 36, 1442-1451, doi:10.1021/es0108988, 2002.

Fine, P. M., Cass, G. R., and Simoneit, B. R. T.: Chemical characterization of fine particle emissions from the fireplace combustion of wood types grown in the Midwestern and Western United States, Environ. Eng. Sci., 21, 387-409, doi:10.1089/109287504323067021, 2004a.

Fine, P. M., Cass, G. R., and Simoneit, B. R. T.: Chemical characterization of fine particle emissions from the wood stove combustion of prevalent United States tree species, Environ. Eng. Sci., 21, 705-721, doi:10.1089/ees.2004.21.705, 2004b.

Fuller, G. W., Tremper, A. H., Baker, T. D., Yttri, K. E., and Butterfield, D.: Contribution of wood burning to PM10 in London, Atmos. Environ., 87, 87-94, doi:10.1016/j.atmosenv.2013.12.037, 2014.

Garg, S., Chandra, B. P., Sinha, V., Sarda-Esteve, R., Gros, V., and Sinha, B.: Limitation of the use of the absorption angstrom exponent for source apportionment of equivalent black carbon: a case study from the North West Indo-Gangetic Plain, Environ. Sci. Technol., 50, 814-824, doi:10.1021/acs.est.5b03868, 2016.

Gelencsér, A.: Carbonaceous Aerosols, Springer, Dordrecht, 2004.

Gelencsér, A., May, B., Simpson, D., Sánchez-Ochoa, A., KasperGiebl, A., Puxbaum, H., Caseiro, A., Pio, C., and Legrand, M.: Source apportionment of PM2.5 organic aerosol over Europe: Primary/secondary, natural/anthropogenic, and fossil/biogenic origin, J. Geophys. Res.-Atmos., 112, D23S04, doi:10.1029/2006JD008094, 2007.

Genberg, J., Denier van der Gon, H. A. C., Simpson, D., Swietlicki, E., Areskoug, H., Beddows, D., Ceburnis, D., Fiebig, M., Hansson, H. C., Harrison, R. M., Jennings, S. G., Saarikoski, S., Spindler, G., Visschedijk, A. J. H., Wiedensohler, A., Yttri, K. E., and Bergström, R.: Light-absorbing carbon in Europe - measurement and modelling, with a focus on residential wood combustion emissions, Atmos. Chem. Phys., 13, 87198738, doi:10.5194/acp-13-8719-2013, 2013.

Gianini, M. F. D., Gehrig, R., Fischer, A., Ulrich, A., Wichser, A., and Hueglin, C.: Chemical composition of PM10 in Switzerland: An analysis for 2008/2009 and changes since 1998/1999, Atmos. Environ., 54, 97-106, doi:10.1016/j.atmosenv.2012.02.037, 2012.

Gilardoni, S., Liu, S., Takahama, S., Russell, L. M., Allan, J. D., Steinbrecher, R., Jimenez, J. L., De Carlo, P. F., Dunlea, E. J., and Baumgardner, D.: Characterization of organic ambient aerosol during MIRAGE 2006 on three platforms, Atmos. Chem. Phys., 9, 5417-5432, doi:10.5194/acp-9-5417-2009, 2009.

Hansen, A. D. A.: The Aethalometer, manual, Magee Scientific, Berkeley, California, USA, 2003.

Hansen, A. D. A., Rosen, H., and Novakov, T.: The Aethalometer - An instrument for the real-time measurement of optical absorption by aerosol particles, Sci. Total Environ., 36, 191-196, doi:10.1016/0048-9697(84)90265-1, 1984.

Harrison, R. M., Beddows, D. C. S., Hu, L., and Yin, J.: Comparison of methods for evaluation of wood smoke and estimation of UK ambient concentrations, Atmos. Chem. Phys., 12, 82718283, doi:10.5194/acp-12-8271-2012, 2012. 
Harrison, R. M., Beddows, D. C. S., Jones, A. M., Calvo, A., Alves, C., and Pio, C.: An evaluation of some issues regarding the use of aethalometers to measure woodsmoke concentrations, Atmos. Environ., 80, 540-548, doi:10.1016/j.atmosenv.2013.08.026, 2013.

Hennigan, C. J., Miracolo, M. A., Engelhart, G. J., May, A. A., Presto, A. A., Lee, T., Sullivan, A. P., McMeeking, G. R., Coe, H., Wold, C. E., Hao, W.-M., Gilman, J. B., Kuster, W. C., de Gouw, J., Schichtel, B. A., Collett Jr., J. L., Kreidenweis, S. M., and Robinson, A. L.: Chemical and physical transformations of organic aerosol from the photo-oxidation of open biomass burning emissions in an environmental chamber, Atmos. Chem. Phys., 11, 7669-7686, doi:10.5194/acp-11-7669-2011, 2011.

Herich, H., Hueglin, C., and Buchmann, B.: A 2.5 year's source apportionment study of black carbon from wood burning and fossil fuel combustion at urban and rural sites in Switzerland, Atmos. Meas. Tech., 4, 1409-1420, doi:10.5194/amt-4-1409-2011, 2011.

Herich, H., Gianini, M. F. D., Piot, C., Močnik, G., Jaffrezo, J. L., Besombes, J. L., Prévôt, A. S. H., and Hueglin, C.: Overview of the impact of wood burning emissions on carbonaceous aerosols and PM in large parts of the Alpine region, Atmos. Environ., 89, 64-75, doi:10.1016/j.atmosenv.2014.02.008, 2014.

Heringa, M. F., DeCarlo, P. F., Chirico, R., Tritscher, T., Dommen, J., Weingartner, E., Richter, R., Wehrle, G., Prévôt, A. S. H., and Baltensperger, U.: Investigations of primary and secondary particulate matter of different wood combustion appliances with a high-resolution time-of-flight aerosol mass spectrometer, Atmos. Chem. Phys., 11, 5945-5957, doi:10.5194/acp-11-59452011, 2011.

Huang, R. J., Zhang, Y. L., Bozzetti, C., Ho, K. F., Cao, J. J., Han, Y. M., Daellenbach, K. R., Slowik, J. G., Platt, S. M., Canonaco, F., Zotter, P., Wolf, R., Pieber, S. M., Bruns, E. A., Crippa, M., Ciarelli, G., Piazzalunga, A., Schwikowski, M., Abbaszade, G., Schnelle-Kreis, J., Zimmermann, R., An, Z. S., Szidat, S., Baltensperger, U., El Haddad, I., and Prevot, A. S. H.: High secondary aerosol contribution to particulate pollution during haze events in China, Nature, 514, 218-222, doi:10.1038/nature13774, 2014.

IPCC: Climate Change 2013: The physical science basis, Contribution of working group I to the fifth assessment report of the Intergovernmental Panel on Climate Change, edited by: Stocker, T. F., Qin, D., Plattner, G.-K., Tignor, M., Allen, S. K., Boschung, J., Nauels, A., Xia, Y., Bex, V., and Midgley, P. M., Cambridge University Press, Cambridge, United Kingdom and New York, NY, USA, 2013.

Jacobson, M. C., Hansson, H. C., Noone, K. J., and Charlson, R. J.: Organic atmospheric aerosols: Review and state of the science, Rev. Geophys., 38, 267-294, doi:10.1029/1998RG000045, 2000.

Jacobson, M. Z.: Strong radiative heating due to the mixing state of black carbon in atmospheric aerosols, Nature, 409, 695-697, doi:10.1038/35055518, 2001.

Jacobson, M. Z.: Short-term effects of controlling fossil-fuel soot, biofuel soot and gases, and methane on climate, Arctic ice, and air pollution health, J. Geophys. Res.-Atmos., 115, D14209, doi:10.1029/2009JD013795, 2010.

Jimenez, J. L., Canagaratna, M. R., Donahue, N. M., Prevot, A. S. H., Zhang, Q., Kroll, J. H., DeCarlo, P. F., Allan, J. D., Coe, H., Ng, N. L., Aiken, A. C., Docherty, K. S., Ulbrich, I. M.,
Grieshop, A. P., Robinson, A. L., Duplissy, J., Smith, J. D., Wilson, K. R., Lanz, V. A., Hueglin, C., Sun, Y. L., Tian, J., Laaksonen, A., Raatikainen, T., Rautiainen, J., Vaattovaara, P., Ehn, M., Kulmala, M., Tomlinson, J. M., Collins, D. R., Cubison, M. J., E, Dunlea, J., Huffman, J. A., Onasch, T. B., Alfarra, M. R., Williams, P. I., Bower, K., Kondo, Y., Schneider, J., Drewnick, F., Borrmann, S., Weimer, S., Demerjian, K., Salcedo, D., Cottrell, L., Griffin, R., Takami, A., Miyoshi, T., Hatakeyama, S., Shimono, A., Sun, J. Y., Zhang, Y. M., Dzepina, K., Kimmel, J. R., Sueper, D., Jayne, J. T., Herndon, S. C., Trimborn, A. M., Williams, L. R., Wood, E. C., Middlebrook, A. M., Kolb, C. E., Baltensperger, U., and Worsnop, D. R.: Evolution of organic aerosols in the atmosphere, Science, 326, 1525-1529, doi:10.1126/science.1180353, 2009.

Kessler, S. H., Smith, J. D., Che, D. L., Worsnop, D. R., Wilson, K. R., and Kroll, J. H.: Chemical sinks of organic aerosol: Kinetics and products of the heterogeneous oxidation of erythritol and levoglucosan, Environ. Sci. Technol., 44, 7005-7010, doi:10.1021/es101465m, 2010.

Kirchstetter, T. W., Novakov, T., and Hobbs, P. V.: Evidence that the spectral dependence of light absorption by aerosols is affected by organic carbon, J. Geophys. Res.-Atmos., 109, D21208, doi:10.1029/2004JD004999, 2004.

Laborde, M., Crippa, M., Tritscher, T., Jurányi, Z., Decarlo, P. F., Temime-Roussel, B., Marchand, N., Eckhardt, S., Stohl, A., Baltensperger, U., Prévôt, A. S. H., Weingartner, E., and Gysel, M.: Black carbon physical properties and mixing state in the European megacity Paris, Atmos. Chem. Phys., 13, 5831-5856, doi:10.5194/acp-13-5831-2013, 2013.

Lack, D. A., Bahreini, R., Langridge, J. M., Gilman, J. B., and Middlebrook, A. M.: Brown carbon absorption linked to organic mass tracers in biomass burning particles, Atmos. Chem. Phys., 13, 2415-2422, doi:10.5194/acp-13-2415-2013, 2013.

Lanz, V. A., Alfarra, M. R., Baltensperger, U., Buchmann, B., Hueglin, C., Szidat, S., Wehrli, M. N., Wacker, L., Weimer, S., Caseiro, A., Puxbaum, H., and Prévôt, A. S. H.: Source attribution of submicron organic aerosols during wintertime inversions by advanced factor analysis of aerosol mass spectra, Environ. Sci. Technol., 42, 214-220, doi:10.1021/es0707207, 2008.

Lanz, V. A., Prévôt, A. S. H., Alfarra, M. R., Weimer, S., Mohr, C., DeCarlo, P. F., Gianini, M. F. D., Hueglin, C., Schneider, J., Favez, O., D'Anna, B., George, C., and Baltensperger, U.: Characterization of aerosol chemical composition with aerosol mass spectrometry in Central Europe: an overview, Atmos. Chem. Phys., 10, 10453-10471, doi:10.5194/acp-10-10453-2010, 2010.

Larsen, B. R., Gilardoni, S., Stenström, K., Niedzialek, J., Jimenez, J., and Belis, C. A.: Sources for PM air pollution in the Po Plain, Italy: II. Probabilistic uncertainty characterization and sensitivity analysis of secondary and primary sources, Atmos. Environ., 50, 203-213, doi:10.1016/j.atmosenv.2011.12.038, 2012.

Levin, I., Naegler, T., Kromer, B., Diehl, M., Francey, R. J., GomezPelaez, A. J., Steele, L. P., Wagenbach, D., Weller, R., and Worthy, D. E.: Observations and modelling of the global distribution and long-term trend of atmospheric ${ }^{14} \mathrm{CO}_{2}$, Tellus B, 62, 26-46, doi:10.1111/j.1600-0889.2009.00446.x, 2010.

Lewis, K., Arnott, W. P., Moosmüller, H., and Wold, C. E.: Strong spectral variation of biomass smoke light absorption and single scattering albedo observed with a novel dual-wavelength pho- 
toacoustic instrument, J. Geophys. Res.-Atmos., 113, D16203, doi:10.1029/2007JD009699, 2008.

Liousse, C., Cachier, H., and Jennings, S. G.: Optical and thermal measurements of black carbon aerosol content in different environments: Variation of the specific attenuation crosssection, sigma $(\sigma)$, Atmos. Environ. A-Gen., 27, 1203-1211, doi:10.1016/0960-1686(93)90246-U, 1993.

Liu, D., Allan, J. D., Young, D. E., Coe, H., Beddows, D., Fleming, Z. L., Flynn, M. J., Gallagher, M. W., Harrison, R. M., Lee, J., Prevot, A. S. H., Taylor, J. W., Yin, J., Williams, P. I., and Zotter, P.: Size distribution, mixing state and source apportionment of black carbon aerosol in London during wintertime, Atmos. Chem. Phys., 14, 10061-10084, doi:10.5194/acp14-10061-2014, 2014.

Mohn, J., Szidat, S., Fellner, J., Rechberger, H., Quartier, R., Buchmann, B., and Emmenegger, L.: Determination of biogenic and fossil $\mathrm{CO}_{2}$ emitted by waste incineration based on $\left(\mathrm{CO}_{2}\right)-\mathrm{C}$ 14 and mass balances, Bioresource Technol., 99, 6471-6479, doi:10.1016/j.biortech.2007.11.042, 2008.

Mohr, C., Lopez-Hilfiker, F. D., Zotter, P., Prévôt, A. S. H., Xu, L., Ng, N. L., Herndon, S. C., Williams, L. R., Franklin, J. P., Zahniser, M. S., Worsnop, D. R., Knighton, W. B., Aiken, A. C., Gorkowski, K. J., Dubey, M. K., Allan, J. D., and Thornton, J. A.: Contribution of nitrated phenols to wood burning brown carbon light absorption in Detling, United Kingdom during winter time, Environ. Sci. Technol., 47, 6316-6324, doi:10.1021/es400683v, 2013.

Moosmüller, H., Arnott, W. P., Rogers, C. F., Bowen, J. L., Gillies, J. A., Pierson, W. R., Collins, J. F., Durbin, T. D., and Norbeck, J. M.: Time-resolved characterization of diesel particulate emissions, 2. instruments for elemental and organic carbon measurements, Environ. Sci. Technol., 35, 1935-1942, doi:10.1021/es0015242, 2001.

Moosmüller, H., Chakrabarty, R. K., Ehlers, K. M., and Arnott, W. P.: Absorption Ångström coefficient, brown carbon, and aerosols: basic concepts, bulk matter, and spherical particles, Atmos. Chem. Phys., 11, 1217-1225, doi:10.5194/acp-11-12172011, 2011.

Park, S. S., Hansen, A. D. A., and Cho, S. Y.: Measurement of real time black carbon for investigating spot loading effects of Aethalometer data, Atmos. Environ., 44, 1449-1455, doi:10.1016/j.atmosenv.2010.01.025, 2010.

Perron, N., Sandradewi, J., Alfarra, M. R., Lienemann, P., Gehrig, R., Kasper-Giebl, A., Lanz, V. A., Szidat, S., Ruff, M., Fahrni, S., Wacker, L., Baltensperger, U., and Prévôt, A. S. H.: Composition and sources of particulate matter in an industrialised Alpine valley, Atmos. Chem. Phys. Discuss., 10, 9391-9430, doi:10.5194/acpd-10-9391-2010, 2010.

Petzold, A., Kopp, C., and Niessner, R.: The dependence of the specific attenuation cross-section on black carbon mass fraction and particle size, Atmos. Environ., 31, 661-672, doi:10.1016/S13522310(96)00245-2, 1997.

Petzold, A., Ogren, J. A., Fiebig, M., Laj, P., Li, S.-M., Baltensperger, U., Holzer-Popp, T., Kinne, S., Pappalardo, G., Sugimoto, N., Wehrli, C., Wiedensohler, A., and Zhang, X.-Y.: Recommendations for reporting "black carbon" measurements, Atmos. Chem. Phys., 13, 8365-8379, doi:10.5194/acp-13-83652013, 2013.
Piazzalunga, A., Belis, C., Bernardoni, V., Cazzuli, O., Fermo, P., Valli, G., and Vecchi, R.: Estimates of wood burning contribution to PM by the macro-tracer method using tailored emission factors, Atmos. Environ., 45, 6642-6649, doi:10.1016/j.atmosenv.2011.09.008, 2011.

Pope, C. A. and Dockery, D. W.: Health effects of fine particulate air pollution: Lines that connect, J. Air Waste Manage. Assoc., 56, 709-742, doi:10.1080/10473289.2006.10464485, 2006.

Putaud, J.-P., Raes, F., Van Dingenen, R., Brüggemann, E., Facchini, M. C., Decesari, S., Fuzzi, S., Gehrig, R., Hüglin, C., Laj, P., Lorbeer, G., Maenhaut, W., Mihalopoulos, N., Müller, K., Querol, X., Rodriguez, S., Schneider, J., Spindler, G., Brink, H. T., Tørseth, K., and Wiedensohler, A.: A European aerosol phenomenology-2: chemical characteristics of particulate matter at kerbside, urban, rural and background sites in Europe, Atmos. Environ., 38, 2579-2595, doi:10.1016/j.atmosenv.2004.01.041, 2004.

Romonosky, D. E., Ali, N. N., Saiduddin, M. N., Wu, M., Lee, H. J., Aiona, P. K., and Nizkorodov, S. A.: Effective absorption cross sections and photolysis rates of anthropogenic and biogenic secondary organic aerosols, Atmos. Environ., 130, 172179, doi:10.1016/j.atmosenv.2015.10.019, 2016.

Ruff, M., Szidat, S., Gäggeler, H. W., Suter, M., Synal, H. A., and Wacker, L.: Gaseous radiocarbon measurements of small samples, Nucl. Instrum. Meth. B, 268, 790-794, doi:10.1016/j.nimb.2009.10.032, 2010.

Saleh, R., Hennigan, C. J., McMeeking, G. R., Chuang, W. K., Robinson, E. S., Coe, H., Donahue, N. M., and Robinson, A. L.: Absorptivity of brown carbon in fresh and photo-chemically aged biomass-burning emissions, Atmos. Chem. Phys., 13, 76837693, doi:10.5194/acp-13-7683-2013, 2013.

Saleh, R., Robinson, E. S., Tkacik, D. S., Ahern, A. T., Liu, S., Aiken, A. C., Sullivan, R. C., Presto, A. A., Dubey, M. K., Yokelson, R. J., Donahue, N. M., and Robinson, A. L.: Brownness of organics in aerosols from biomass burning linked to their black carbon content, Nat. Geosci., 7, 647-650, doi:10.1038/ngeo2220, 2014.

Sandradewi, J., Prevot, A. S. H., Szidat, S., Perron, N., Alfarra, M. R., Lanz, V. A., Weingartner, E., and Baltensperger, U.: Using aerosol light absorption measurements for the quantitative determination of wood burning and traffic emission contributions to particulate matter, Environ. Sci. Technol., 42, 3316-3323, doi:10.1021/es702253m, 2008a.

Sandradewi, J., Prévôt, A. S. H., Alfarra, M. R., Szidat, S., Wehrli, M. N., Ruff, M., Weimer, S., Lanz, V. A., Weingartner, E., Perron, N., Caseiro, A., Kasper-Giebl, A., Puxbaum, H., Wacker, L., and Baltensperger, U.: Comparison of several wood smoke markers and source apportionment methods for wood burning particulate mass, Atmos. Chem. Phys. Discuss., 8, 8091-8118, doi:10.5194/acpd-8-8091-2008, 2008b.

Sandradewi, J., Prevot, A. S. H., Weingartner, E., Schmidhauser, R., Gysel, M., and Baltensperger, U.: A study of wood burning and traffic aerosols in an Alpine valley using a multi-wavelength Aethalometer, Atmos. Environ., 42, 101-112, doi:10.1016/j.atmosenv.2007.09.034, 2008c.

Schauer, J. J., Kleeman, M. J., Cass, G. R., and Simoneit, B. R. T.: Measurement of emissions from air pollution sources. 3. C1-C29 organic compounds from fireplace combustion of wood, Environ. Sci. Technol., 35, 1716-1728, doi:10.1021/es001331e, 2001. 
Schmid, H., Laskus, L., Abraham, H. J., Baltensperger, U., Lavanchy, V., Bizjak, M., Burba, P., Cachier, H., Crow, D., Chow, J., Gnauk, T., Even, A., ten Brink, H. M., Giesen, K.P., Hitzenberger, R., Hueglin, C., Maenhaut, W., Pio, C., Carvalho, A., Putaud, J.-P., Toom-Sauntry, D., and Puxbaum, H.: Results of the "carbon conference" international aerosol carbon round robin test stage I, Atmos. Environ., 35, 2111-2121, doi:10.1016/S1352-2310(00)00493-3, 2001.

Schmidl, C., Marr, I. L., Caseiro, A., Kotianová, P., Berner, A., Bauer, H., Kasper-Giebl, A., and Puxbaum, H.: Chemical characterisation of fine particle emissions from wood stove combustion of common woods growing in midEuropean Alpine regions, Atmos. Environ., 42, 126-141, doi:10.1016/j.atmosenv.2007.09.028, 2008.

Schnaiter, M., Horvath, H., Möhler, O., Naumann, K. H., Saathoff, H., and Schöck, O. W.: UV-VIS-NIR spectral optical properties of soot and soot-containing aerosols, J. Aerosol Sci., 34, 14211444, doi:10.1016/S0021-8502(03)00361-6, 2003.

Schnaiter, M., Linke, C., Möhler, O., Naumann, K. H., Saathoff, H., Wagner, R., Schurath, U., and Wehner, B.: Absorption amplification of black carbon internally mixed with secondary organic aerosol, J. Geophys. Res.-Atmos., 110, D19204, doi:10.1029/2005JD006046, 2005.

Segura, S., Estellés, V., Titos, G., Lyamani, H., Utrillas, M. P., Zotter, P., Prévôt, A. S. H., Mocnik, G., Alados-Arboledas, L., and Martínez-Lozano, J. A.: Determination and analysis of in situ spectral aerosol optical properties by a multi-instrumental approach, Atmos. Meas. Tech., 7, 2373-2387, doi:10.5194/amt-72373-2014, 2014.

Sharpless, C. M., Aeschbacher, M., Page, S. E., Wenk, J., Sander, M., and McNeill, K.: Photooxidation-induced changes in optical, electrochemical, and photochemical properties of humic substances, Environ. Sci. Technol., 48, 2688-2696, doi:10.1021/es403925g, 2014.

Shindell, D., Kuylenstierna, J. C. I., Vignati, E., van Dingenen, R., Amann, M., Klimont, Z., Anenberg, S. C., Muller, N., JanssensMaenhout, G., Raes, F., Schwartz, J., Faluvegi, G., Pozzoli, L., Kupiainen, K., Höglund-Isaksson, L., Emberson, L., Streets, D., Ramanathan, V., Hicks, K., Oanh, N. T. K., Milly, G., Williams, M., Demkine, V., and Fowler, D.: Simultaneously mitigating near-term climate change and improving human health and food security, Science, 335, 183-189, doi:10.1126/science.1210026, 2012.

Stroud, C. A., Moran, M. D., Makar, P. A., Gong, S., Gong, W., Zhang, J., Slowik, J. G., Abbatt, J. P. D., Lu, G., Brook, J. R., Mihele, C., Li, Q., Sills, D., Strawbridge, K. B., McGuire, M. L., and Evans, G. J.: Evaluation of chemical transport model predictions of primary organic aerosol for air masses classified by particle component-based factor analysis, Atmos. Chem. Phys., 12, 8297-8321, doi:10.5194/acp-12-8297-2012, 2012.

Stuiver, M. and Polach, H. A.: Reporting of C-14 data-discussion, Radiocarbon, 19, 355-363, 1977.

Sun, Y. L., Zhang, Q., Schwab, J. J., Chen, W.-N., Bae, M.-S., Hung, H.-M., Lin, Y.-C., Ng, N. L., Jayne, J., Massoli, P., Williams, L. R., and Demerjian, K. L.: Characterization of near-highway submicron aerosols in New York City with a high-resolution aerosol mass spectrometer, Atmos. Chem. Phys., 12, 2215-2227, doi:10.5194/acp-12-2215-2012, 2012.
Synal, H. A., Stocker, M., and Suter, M.: MICADAS: A new compact radiocarbon AMS system, Nucl. Instrum. Meth. B, 259, 713, doi:10.1016/j.nimb.2007.01.138, 2007.

Szidat, S.: Sources of Asian haze, Science, 323, 470-471, doi:10.1126/science.1169407, 2009.

Szidat, S., Jenk, T. M., Gäggeler, H. W., Synal, H. A., Hajdas, I., Bonani, G., and Saurer, M.: THEODORE, a two-step heating system for the EC/OC determination of radiocarbon $\left({ }^{14} \mathrm{C}\right)$ in the environment, Nucl. Instrum. Meth. B, 223-224, 829-836, doi:10.1016/j.nimb.2004.04.153, 2004.

Szidat, S., Jenk, T. M., Synal, H. A., Kalberer, M., Wacker, L., Hajdas, I., Kasper-Giebl, A., and Baltensperger, U.: Contributions of fossil fuel, biomass-burning, and biogenic emissions to carbonaceous aerosols in Zurich as traced by ${ }^{14} \mathrm{C}$, J. Geophys. Res.Atmos., 111, D07206, doi:10.1029/2005JD006590, 2006.

Szidat, S., Prévôt, A. S. H., Sandradewi, J., Alfarra, M. R., Synal, H.-A., Wacker, L., and Baltensperger, U.: Dominant impact of residential wood burning on particulate matter in Alpine valleys during winter, Geophys. Res. Lett., 34, L05820, doi:10.1029/2006GL028325, 2007.

Szidat, S., Bench, G., Bernardoni, V., Calzolai, G., Czimczik, C. I., Derendorp, L., Dusek, U., Elder, K., Fedi, M. E., Genberg, J., Gustafsson, O., Kirillova, E., Kondo, M., McNichol, A. P., Perron, N., Santos, G. M., Stenstrom, K., Swietlicki, E., Uchida, M., Vecchi, R., Wacker, L., Zhang, Y. L., and Prévôt, A. S. H.: Intercomparison of C-14 analysis of carbonaceous aerosols: exercise 2009, Radiocarbon, 55, 1496-1509, doi:10.2458/azu_js_rc.55.16314, 2013.

Szidat, S., Salazar, G. A., Vogel, E., Battaglia, M., Wacker, L., Synal, H.-A., and Türler, A.: ${ }^{14} \mathrm{C}$ analysis and sample preparation at the new Bern Laboratory for the Analysis of Radiocarbon with AMS (LARA), Radiocarbon, 56, 561-566, doi:10.2458/56.17457, 2014.

Vecchi, R., Bernardoni, V., Paganelli, C., and Valli, G.: A filterbased light-absorption measurement with polar photometer: Effects of sampling artefacts from organic carbon, J. Aerosol Sci., 70, 15-25, doi:10.1016/j.jaerosci.2013.12.012, 2014.

Wacker, L., Christl, M., and Synal, H. A.: Bats: A new tool for AMS data reduction, Nucl. Instrum. Meth. B, 268, 976-979, doi:10.1016/j.nimb.2009.10.078, 2010.

Wacker, L., Fahrni, S. M., Hajdas, I., Molnar, M., Synal, H. A., Szidat, S., and Zhang, Y. L.: A versatile gas interface for routine radiocarbon analysis with a gas ion source, Nucl. Instrum. Meth. B, 294, 315-319, doi:10.1016/j.nimb.2012.02.009, 2013.

Weingartner, E., Saathoff, H., Schnaiter, M., Streit, N., Bitnar, B., and Baltensperger, U.: Absorption of light by soot particles: determination of the absorption coefficient by means of aethalometers, J. Aerosol Sci., 34, 1445-1463, doi:10.1016/s00218502(03)00359-8, 2003.

WHO: Air Quality Guidelines for Particulate Matter, Ozone, Nitrogen Dioxide and Sulfur Dioxide, Global Update 2005, Summary of Risk Assessment, World Health Organization, document WHO/SDE/PHE/OEH/06.02, Geneva, 2006.

WHO: The World Health Organization, 7 million premature deaths annually linked to air pollution, available at: http://www.who.int/ mediacentre/news/releases/2014/air-pollution/en/ (last access: 9 March 2017), 2014.

Zanatta, M., Gysel, M., Bukowiecki, N., Müller, T., Weingartner, E., Areskoug, H., Fiebig, M., Yttri, K. E., Mihalopoulos, N., Kou- 
varakis, G., Beddows, D., Harrison, R. M., Cavalli, F., Putaud, J. P., Spindler, G., Wiedensohler, A., Alastuey, A., Pandolfi, M., Sellegri, K., Swietlicki, E., Jaffrezo, J. L., Baltensperger, U., and Laj, P.: A European aerosol phenomenology-5: Climatology of black carbon optical properties at 9 regional background sites across Europe, Atmos. Environ., 145, 346-364, doi:10.1016/j.atmosenv.2016.09.035, 2016.

Zhang, Q., Worsnop, D. R., Canagaratna, M. R., and Jimenez, J. L.: Hydrocarbon-like and oxygenated organic aerosols in Pittsburgh: insights into sources and processes of organic aerosols, Atmos. Chem. Phys., 5, 3289-3311, doi:10.5194/acp-5-32892005, 2005.

Zhang, Y. L., Perron, N., Ciobanu, V. G., Zotter, P., Minguillón, M. C., Wacker, L., Prévôt, A. S. H., Baltensperger, U., and Szidat, S.: On the isolation of OC and EC and the optimal strategy of radiocarbon-based source apportionment of carbonaceous aerosols, Atmos. Chem. Phys., 12, 10841-10856, doi:10.5194/acp-12-10841-2012, 2012.
Zhong, M. and Jang, M.: Dynamic light absorption of biomassburning organic carbon photochemically aged under natural sunlight, Atmos. Chem. Phys., 14, 1517-1525, doi:10.5194/acp-141517-2014, 2014.

Zotter, P., Ciobanu, V. G., Zhang, Y. L., El-Haddad, I., Macchia, M., Daellenbach, K. R., Salazar, G. A., Huang, R.-J., Wacker, L., Hueglin, C., Piazzalunga, A., Fermo, P., Schwikowski, M., Baltensperger, U., Szidat, S., and Prévôt, A. S. H.: Radiocarbon analysis of elemental and organic carbon in Switzerland during winter-smog episodes from 2008 to 2012 - Part 1: Source apportionment and spatial variability, Atmos. Chem. Phys., 14, 1355113570, doi:10.5194/acp-14-13551-2014, 2014. 